Research Article

\title{
Selective Hydrogenation of Stearic Acid to 1-Octadecanol Using Bimetallic Palladium-Tin Supported on Carbon Catalysts at Mild Reaction Conditions
}

\author{
R. Rodiansono ${ }^{1,2, *}$, Elisa Hayati ${ }^{1}$, Atina Sabila Azzahra ${ }^{1}$, Maria Dewi Astuti ${ }^{1}$, Kamilia \\ Mustikasari ${ }^{1}$, Sadang Husain ${ }^{2,3}$, S. Sutomo ${ }^{4}$ \\ ${ }^{1}$ Department of Chemistry, Faculty of Mathematics and Natural Sciences, Lambung Mangkurat \\ University, Jl. A. Yani Km 36.0 Banjarbaru South Kalimantan, Indonesia. \\ ${ }^{2}$ Catalysis for Sustainable Energy and Environment (CATSuRe), Lambung Mangkurat University, \\ Indonesia. \\ ${ }^{3}$ Department of Physics, Faculty of Mathematics and Natural Sciences, Lambung Mangkurat \\ University, Jl. A. Yani Km 36 Banjarbaru, 70714, Indonesia. \\ ${ }^{4}$ Department of Pharmacy, Faculty of Mathematics and Natural Sciences, Lambung Mangkurat \\ University, Jl. A. Yani Km 36 Banjarbaru, 70714, Indonesia.
}

Received: 29th July 2021; Revised: $19^{\text {th }}$ September 2021; Accepted: $19^{\text {th }}$ September 2021 Available online: 20th September 2021; Published regularly: December 2021

\section{Abstract}

Bimetallic palladium-tin catalysts supported on microporous carbon (denoted as $\mathrm{Pd}-\mathrm{Sn}(x) / \mathrm{C}$, loading amount of $\mathrm{Pd}$ $=5 \mathrm{wt} \%$ and $x=\mathrm{Pd} / \mathrm{Sn}$ molar ratio; c.a. $3.0 ; 1.5$; and 1.0) showed high selectivity in the hydrogenation of stearic acid towards 1-octadecanol (stearyl alcohol) under mild reaction conditions. $\mathrm{Pd}-\mathrm{Sn}(x) / \mathrm{C}$ catalysts were synthesized via the hydrothermal method at temperature of $150{ }^{\circ} \mathrm{C}$ for $24 \mathrm{~h}$, and reduced with $\mathrm{H}_{2}$ at $400{ }^{\circ} \mathrm{C}$ for $3 \mathrm{~h}$. $\mathrm{Pd}$ $\operatorname{Sn}(1.5) / C$ catalyst exhibited the highest yield of stearyl alcohol (1-octadecanol) (up to 73.2\%) at 100\% conversion of stearic acid at temperature $240{ }^{\circ} \mathrm{C}$, initial $\mathrm{H}_{2}$ pressure of $3.0 \mathrm{MPa}$, a reaction time of $13 \mathrm{~h}$, and in 2-propanol/water solvent. The high selectivity of alcohols over $\mathrm{Pd}-\mathrm{Sn}(1.5) / \mathrm{C}$ catalyst can be attributed to the formation of bimetallic $\mathrm{Pd}-\mathrm{Sn}$ alloy phases (e.g. $\mathrm{Pd}_{3} \mathrm{Sn}$ and $\left.\mathrm{Pd}_{3} \mathrm{Sn}_{2}\right)$ as obviously depicted by XRD analysis. The presence of co-promotor $\mathrm{Sn}$ and the formation of bimetallic may play a pivotal role in the high selectivity of 1-octadecanol.

Copyright (C 2021 by Authors, Published by BCREC Group. This is an open access article under the CC BY-SA License (https://creativecommons.org/licenses/by-sa/4.0).

Keywords: hydrogenation; stearic acid; 1-octadecanol; bimetallic Pd-Sn catalyst

How to Cite: R. Rodiansono, E. Hayati, A.S. Azzahra, M.D. Astuti, K. Mustikasari, S. Husain, S. Sutomo (2021). Selective Hydrogenation of Stearic Acid to 1-Octadecanol Using Bimetallic Palladium-Tin Supported on Carbon Catalysts at Mild Reaction Conditions. Bulletin of Chemical Reaction Engineering \& Catalysis, 16(4), 888-903 (doi:10.9767/bcrec.16.4.11895.888-903)

Permalink/DOI: https://doi.org/10.9767/bcrec.16.4.11895.888-903

\section{Introduction}

Fatty alcohols are non-ionic surfactants widely used as lubricants, emulsifiers, polymers, oil additives, emollients and thickeners in

* Corresponding Author.

Email: rodiansono@ulm.ac.id (R. Rodiansono);

Telp: +62-511-4773112, Fax: +62-511-4773112 alimentary, cosmetic industries, and intermediate of biofuel synthesis [1]. Fatty alcohols can be produced from the catalytic hydrogenation of fatty acids using both heterogeneous and homogeneous catalysts is the important step in the transformation of biobased resources [2-7]. Commercially, the production of fatty alcohols involves methanolysis of triglycerides or fatty 
acids, followed by hydrogenolysis using copper chromite catalysts at temperatures ranging from 200 to $400{ }^{\circ} \mathrm{C}$ and $\mathrm{H}_{2}$ pressures of $20-50$ $\mathrm{MPa}$ [8-10]. In this regard, the development of catalysts to produce fatty alcohols under milder conditions has been a long-standing industrial target. Moreover, chromium catalysts are not environmentally friendly; therefore, the development of chromium-free catalysts is highly desired in order to reduce the environmental pollution.

Since the catalytic conversion of biomassderived fatty acids involved the decarbonylation, decarboxylation, and deoxygenation/hydrogenation reactions, the yield of desired products may be depended on the catalyst types or/and the reaction conditions [9,11-13]. Noble platinum metal group (PGM), such as: $\mathrm{Pt}, \mathrm{Ru}, \mathrm{Rh}, \mathrm{Pd}$ catalysts, were reported to be active in the selective hydrogenation of fatty acids, however the selectivity towards desired product of fatty alcohols was in wide range of moderate to high [14]. To enhance the selectivity of PGM metal catalysts, the modification of those metals is necessary; i.e. the addition of more electropositive metals (e.g. Sn and In) $[15,16]$ or oxophilic metal oxides, such as $\mathrm{MoO}_{\mathrm{x}}$ and $\mathrm{ReO}_{\mathrm{x}}$ [17], or the use of oxide supports that strongly interact with the active metals (e.g. $\mathrm{TiO}_{2}$ and $\mathrm{Nb}_{2} \mathrm{O}_{5}$ ) [18,19]. Many kinds of $\mathrm{Ru}-$ based catalysts have been studied [20-23], from which bimetallic supported $\mathrm{Ru}_{3} \mathrm{Sn}_{7}$ nanocluster catalyst showed the highest selectivity towards fatty alcohols $\left(240^{\circ} \mathrm{C}, 4.0 \mathrm{MPa}\right.$ $\mathrm{H}_{2}$, and $120 \mathrm{~min}$ ) in coconut oil hydrogenation
[24]. A maximum yield of fatty alcohol was 98.6\%, which obtained using $\mathrm{Ru}_{3} \mathrm{Sn}_{7}$ nanocluster containing trace amount of $\mathrm{SnO}$ species $[25,26]$. Pt/TiO 2 catalyst was reported to be effective for carboxylic acids hydrogenation, and enhanced hydrogenation activity could be achieved after modified catalyst with Re without the alcohol selectivity loss [27]. Tomishige and co-workers reported that a moderate conversion of stearic acid (79\%) to stearyl alcohol with selectivity up to $90 \%$ at mild reaction conditions (2.0 MPa, $130{ }^{\circ} \mathrm{C}$ ) was achieved by using oxometallic rhenium oxide-platinum supported on titanium oxide $\left(\mathrm{Pt}-\mathrm{Re} / \mathrm{TiO}_{2}\right)$ catalyst $[28,29]$. The presence $\mathrm{ReO}_{\mathrm{x}}$ species in $\mathrm{ReO}_{\mathrm{x}}$ $\mathrm{Pd} / \mathrm{SiO}_{2}$ greatly improved the hydrogenation rate of stearic acid conversion to high selectivity of 1-octadecanol. The high catalytic activity of $\mathrm{ReO}-\mathrm{Pd} / \mathrm{SiO}_{2}$ could be attributed to the presence of the intermediate oxidation state of $\mathrm{Re}^{\mathrm{n}+}$ such as $\mathrm{Re}^{3+}$ and/or $\mathrm{Re}^{4+}$ that can play a crucial role on the formation of the catalytically active site [29]. Moreover, Murzin et al. [30] reported that $4 \mathrm{wt} \% \mathrm{ReO}_{\mathrm{x}} / \mathrm{TiO}_{2}$ catalyst showed high conversion of stearic acid to high yield of 1 -octadecanol $(>93 \%)$ at $200{ }^{\circ} \mathrm{C}$ and $4.0 \mathrm{MPa} \mathrm{H}_{2}$. They reported that a high yield of 1-octadecanol was attributed to a strong adsorption of the acid compared to alcohol on the catalyst, which inhibits firther alcohol transformation to alkanes [30]. However, the use of noble metal-based catalysts and low substrate loading is not economic and less viability in the upgrading of biomass-derived platform industry. Therefore,

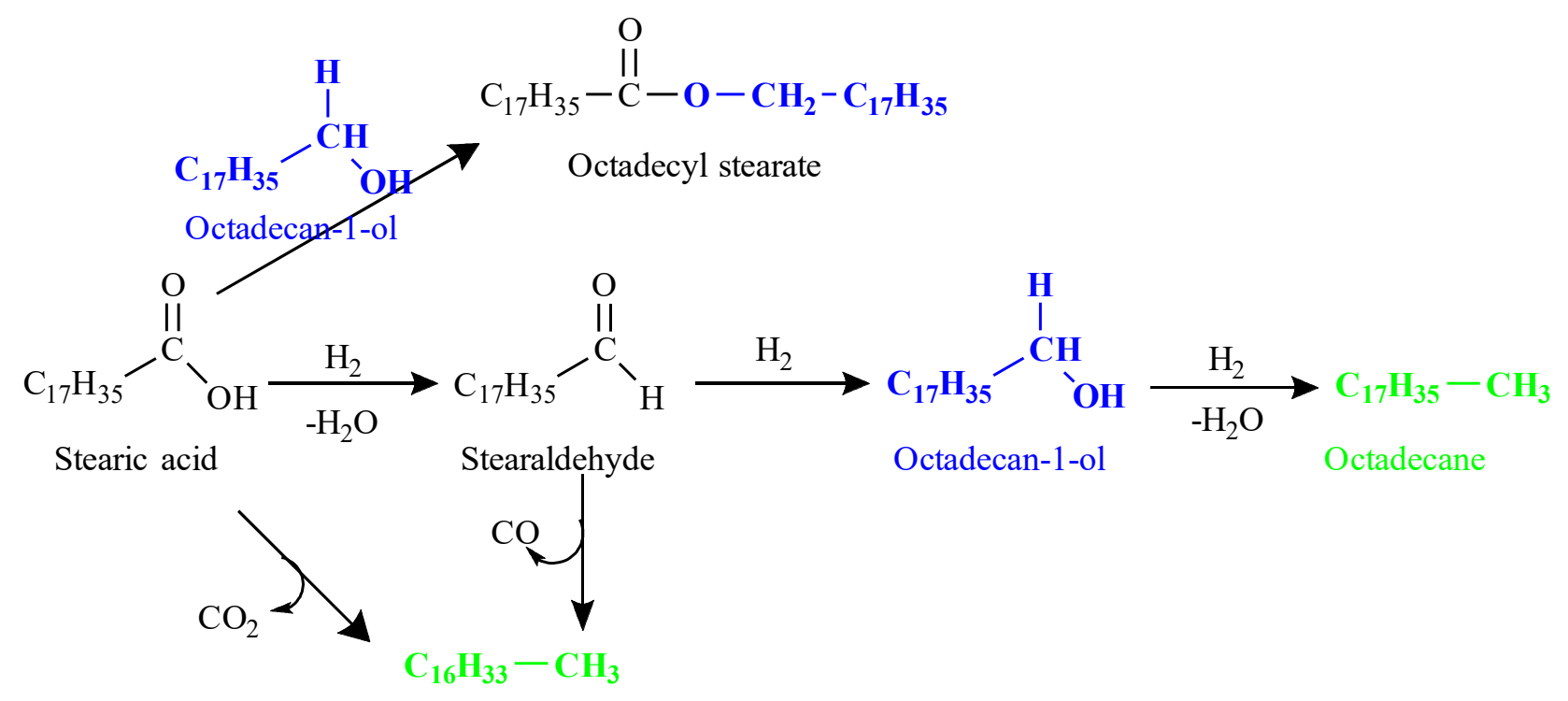

Heptadecane

Scheme 1. Conceived reaction routes for the catalytic transformation of stearic acid to stearyl alcohol (1-octadecanol) using heterogeneous catalysts. 
alternative economical and eco-friendly heterogeneous catalysts that would ensure the preferred hydrogenation of the carboxylic acids (fatty acid) to fatty alcohols are highly desired (Scheme 1).

Palladium catalysts were disclosed in the patent and journal literatures as being capable of hydrogenating of carbonyl compounds to alcohols and high overall activity in the deoxygenating carboxylic acid to alkanes under hydrothermal atmosphere [31,32]. Commercial 5 wt $\% \mathrm{Pd} / \mathrm{C}$ catalyst has been studied extensively for deoxygenation of fatty acid to alkanes at temperature of $160-230{ }^{\circ} \mathrm{C}$ both in presence or in absence of hydrogen [33-37]. Moreover, bimetallic unlike tin modified-Ru or rhenium oxide modified-Pt catalysts, the utilization of bimetallic palladium-tin $(\mathrm{Pd}-\mathrm{Sn})$ catalysts for the hydrogenation of carboxylic acid to alcohols are rarely investigated. $\mathrm{Ru}-\mathrm{Sn}$ catalyst have showed to be superior heterogeneous catalysts for the selective synthesis of fatty alcohols from fatty acids [5,38]. The obtained yield of GVL over bimetallic $\mathrm{Ru}-\mathrm{Fe} / \mathrm{TiO}_{2}$ was $52.4 \%$ that much higher than that of monometallic counterpart $\mathrm{Ru} / \mathrm{TiO}_{2}(22.7 \%)$ [39]. In this regard, Damayanti et al. reported the use of bimetallic $\mathrm{Pd}-\mathrm{Fe} / \mathrm{TiO}_{2}$ catalyst for the hydrogenation of levulinic acid (LA) to $\gamma$-valerolactone (GVL) at $170{ }^{\circ} \mathrm{C}, \quad 3.0 \mathrm{MPa} \mathrm{H}_{2}$ for $7 \mathrm{~h}$. Bimetallic $\mathrm{Ni}-\mathrm{Sn}(1.5) / \mathrm{TiO}_{2}$ catalyst showed high yield of lauryl alcohol at $(97 \%)$ at $>99 \%$ conversion of

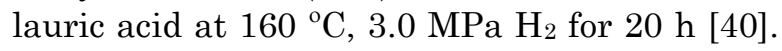
Additionally, in our recent published work, we reported that the promotion effect of $\mathrm{Cu}$ in bimetallic $\mathrm{Pd}-\mathrm{Cu} / \mathrm{C}$ catalyst greatly increased the affinity of $\mathrm{Pd}-\mathrm{Cu}$ toward hydrogenation of carbonyl group of unsaturated compounds, leading to high selectivity of unsaturated alcohols [41].

In this paper, we report the selective hydrogenation of stearic acid to 1-octadecanol (stearyl alcohol) using supported bimetallic palladium-tin on microporous carbon (denoted as $\mathrm{Pd}-\mathrm{Sn}(x) / \mathrm{C}$, loading amount of $\mathrm{Pd}$ is $5 \% \mathrm{wt}$ and $x=\mathrm{Pd} / \mathrm{Sn}$ molar ratio; c.a. $3.0 ; 1.5$; and 1.0) catalysts under moderate reaction conditions. $\mathrm{Pd}-\mathrm{Sn}(x) / \mathrm{C}$ catalyst has been synthesized via the hydrothermal method at temperature of $150{ }^{\circ} \mathrm{C}$ for $24 \mathrm{~h}$, and reducted with $\mathrm{H}_{2}$ at $400{ }^{\circ} \mathrm{C}$ for $3 \mathrm{~h}$. $\mathrm{Pd}-\mathrm{Sn}(1.5) / \mathrm{C}$ catalyst exhibited the highest yield of 1-octadecanol (73.1\%) at $100 \%$ stearic acid conversion at $240{ }^{\circ} \mathrm{C}, 3.0 \mathrm{MPa} \mathrm{H}_{2}$, in 2-propanol/ $\mathrm{H}_{2} \mathrm{O}$ and after $13 \mathrm{~h}$. The effect of reaction temperature, initial $\mathrm{H}_{2}$ pressure, and reaction time on the conversion and product distribution is discussed systematically.

\section{Materials and Methods}

\subsection{Materials}

Palladium (II) acetate $\left(\mathrm{Pd}\left(\mathrm{CH}_{3} \mathrm{COO}\right)_{2} ; 98 \%\right)$ and tin (II) chloride dihydrate $\left(\mathrm{SnCl}_{2} .2 \mathrm{H}_{2} \mathrm{O}\right.$; 99\%) were purchased from WAKO Pure Chemical Industries, Ltd), active carbon $\left(S_{\mathrm{BET}}=815\right.$ $\left.\mathrm{m}^{2} / \mathrm{g}\right)$, Y-Zeolit , HZSM-5 Si/Al $85\left(S_{\mathrm{BET}}=417\right.$ $\mathrm{m}^{2} / \mathrm{g} ; \quad V \mathrm{p}=0.225 \mathrm{~cm}^{3} / \mathrm{g}$; pore diameter $=3.64$ $\mathrm{nm}), \mathrm{Nb}_{2} \mathrm{O}_{5}$ dan $\mathrm{TiO}_{2}$ anatase were purchased and used as received from WAKO Pure Chemical Industries, Ltd. $\gamma-\mathrm{Al}_{2} \mathrm{O}_{3}\left(S_{\mathrm{BET}}=100 \mathrm{~m}^{2} / \mathrm{g}\right)$ was purchased from Japan Aerosil Co. Commercial $5 \mathrm{wt} \% \mathrm{Pd} / \mathrm{C}$, Ethanol (96.0\%; Merck Millipore), ethylene glycol (EG) (99.5\%; Merck Millipore), $\mathrm{NaBH}_{4}$ (95.0\%; Tokyo Chemical Industry(TCI)), $\mathrm{NaOH}$ (99.0\%; Merck Millipore). Stearic acid (98\%; TCI), 1-octadecanol (98\%; TCI), heptadecane (99\%; TCI), dodecane (99\%, TCI) were purchased from Tokyo Chemical Industries Co. (TCI) and used as received.

\subsection{Methods}

\subsubsection{Catalyst preparation}

A typical procedure of the synthesis of supported bimetallic $\mathrm{Pd}-\mathrm{Sn}(1.5) / \mathrm{C}(\mathrm{Pd}=5 \mathrm{wt} \%$ and $\mathrm{Pd} / \mathrm{Sn}$ feeding molar ratio of 1.5 ) catalyst is described as follows [42]: $\mathrm{Pd}\left(\mathrm{CH}_{3} \mathrm{COO}\right)_{2}$ $(0.4613 \mathrm{mmol})$ was dissolved in deionised water (denoted as solution A), and $\mathrm{SnCl}_{2} \cdot 2 \mathrm{H}_{2} \mathrm{O}$ $(0.2947 \mathrm{mmol})$ was dissolved in ethanol/ethylene glycol (20: $10 \mathrm{v} / \mathrm{v} \mathrm{ml}$ ) (denoted as solution B) at room temperature. Solutions $\mathrm{A}$ and $\mathrm{B}$, and $1.0 \mathrm{~g}$ of support (microporous C; $S_{\text {BET }}=815 \mathrm{~m}^{2} \cdot \mathrm{g}^{-1}$ ) were mixed at room temperature; the temperature was subsequently raised to $50{ }^{\circ} \mathrm{C}$ and the mixture was gentle stirred for $12 \mathrm{~h}$. The $\mathrm{pH}$ of the mixture was adjusted to 12 through the dropwise addition of an aqueous solution of $\mathrm{NaOH}$ (3.1 M or 6.0 M). The mixture was then placed into a sealed-Teflon autoclave for the hydrothermal reaction at $150{ }^{\circ} \mathrm{C}$ for $24 \mathrm{~h}$. The resulting black precipitate was filtered, washed with distilled water, and then dried under vacuum overnight. Prior to the catalytic reaction, the obtained black powder was reduced with hydrogen $\left(\mathrm{H}_{2}\right)$ gas at $400{ }^{\circ} \mathrm{C}$ for $3 \mathrm{~h}$ [43]. For comparison and study of support effects, $\mathrm{Pd}-\mathrm{Sn}(1.5)$ supported on various support materials such as $\mathrm{Nb}_{2} \mathrm{O}_{5}, \mathrm{TiO}_{2}, \gamma-\mathrm{Al}_{2} \mathrm{O}$, and typical Y-zeolite and HZSM-5 were also prepared using the same procedure. 


\subsubsection{Characterizations}

The prepared catalysts were characterized by powder X-ray diffraction on a RIGAKU MINIFLEX 600 instrument using monochromatic $\mathrm{CuK} \alpha$ radiation $(\lambda=0.15418$ $\mathrm{nm})$. It was operated at $40 \mathrm{kV}$ and $20 \mathrm{~mA}$ with a step width of $0.02^{\circ}$ and a scan speed of $5^{\circ}$ $\mathrm{min}^{-1}$. The mean crystallite size of Ni was calculated from the full width at half maximum (FWHM) of the Pd(111) diffraction peak according to the Scherrer`s equation.

Nitrogen adsorption isotherms at $-196^{\circ} \mathrm{C}$ were measured using a Belsorp Max (BEL Japan). The samples were degassed at $200{ }^{\circ} \mathrm{C}$ for $2 \mathrm{~h}$ to remove physisorbed gases prior to the measurement. The amount of nitrogen adsorbed onto the samples was used to calculate the specific surface area by means of the BET equation. The total pore volume was estimated to be the liquid volume of nitrogen at a relative pressure of about 0.995. The Barrett-JoynerHalenda (BJH) and Horvath-Kawazoe (HK) approaches were used to calculate total pore volume and pore size distribution from desorption data [44].

The ammonia-temperature programmeddesorption $\left(\mathrm{NH}_{3}\right.$-TPD) was carried out on a Belsorp Max (BEL Japan). The samples were degassed at elevated temperature of $100-200{ }^{\circ} \mathrm{C}$ for $2 \mathrm{~h}$ to remove physisorbed gases prior to the measurement. The temperature was then kept at $200{ }^{\circ} \mathrm{C}$ for $2 \mathrm{~h}$ while flushed with $\mathrm{He}$ gas. $\mathrm{NH}_{3}$ gas (balanced $\mathrm{NH}_{3}, 80 \%$ and $\mathrm{He}, 20 \%$ ) was introduced at $373 \mathrm{~K}$ for $30 \mathrm{~min}$, then evacuated by helium gas to remove the physisorbed also for $30 \mathrm{~min}$. Finally, temperature programmed desorption was carried out at temperature of $100-900{ }^{\circ} \mathrm{C}$ and the desorbed $\mathrm{NH}_{3}$ was monitored by TCD.

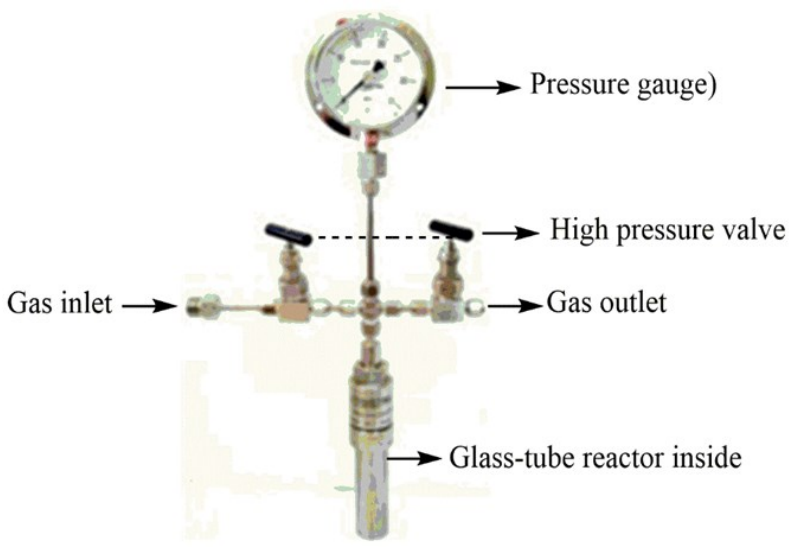

Figure 1. Typical batch system reactor of TAIATSU techno with glass-fitted inside (volume: $30 \mathrm{~mL}$, max. $35 \mathrm{MPa}, 300{ }^{\circ} \mathrm{C}$ ).
The active surface areas were determined by $\mathrm{H}_{2}$ chemisorption. After the catalyst was heated at $120^{\circ} \mathrm{C}$ under vacuum for $30 \mathrm{~min}$, it was heated at $400{ }^{\circ} \mathrm{C}$ under $\mathrm{H}_{2}$ for 30 min and under vacuum for $30 \mathrm{~min}$, followed by evacuation to room temperature for $30 \mathrm{~min}$. The adsorption of $\mathrm{H}_{2}$ was conducted at $0{ }^{\circ} \mathrm{C}$. The active surface area was calculated from the volume of $\mathrm{H}_{2}$ desorbed by assuming an H/Pd stoichiometry of one, respectively and the number of $\mathrm{Pd}$ atom for the (111) plane is $1.5 \times 10^{15}$ per $\mathrm{cm}^{2} \mathrm{Pd}$ based on an equal distribution of the three lowest index planes of $\mathrm{Pd}$ [45].

The interaction of reactant and product adsorbed on the surface of catalyst post the reaction was monitored by attenuated total reflection-infrared (ATR-IR) using Bruker Diamond at wavenumber of $400-4000 \mathrm{~cm}^{-1}$.

\subsubsection{Catalytic reactions testing}

A typical procedure for hydrogenation of stearic acid is described as follows: catalyst $\mathrm{Pd}-\mathrm{Sn}(1.5) / \mathrm{C}(0.05 \mathrm{~g})$, stearic acid $(0.2844 \mathrm{~g}$; $1.0 \mathrm{mmol})$, 2-propanol: $\mathrm{H}_{2} \mathrm{O}(5 \mathrm{ml} ; 4.0: 1.0 \mathrm{v} / \mathrm{v})$ as solvent were placed into a glass reaction tube, which fitted inside a stainless steel reactor (Figure 1). After $\mathrm{H}_{2}$ was introduced into the reactor with an initial $\mathrm{H}_{2}$ pressure of 3.0 $\mathrm{MPa}$ at room temperature, the temperature of the reactor was increased to $240{ }^{\circ} \mathrm{C}$ using electric furnace, $800 \mathrm{rpm}$. After $7 \mathrm{~h}$, the reactor was cooled to room temperature, internal standard of dodecane was added and the conversion of stearic acid and the yield of 1 octadecanol were determined by GC analysis. The $\mathrm{Pd}-\mathrm{Sn}(1.5) / \mathrm{C}$ catalyst was easily separated using either simple centrifugation or filtration.

\subsubsection{Product Analysis}

GC analysis of the reactant (stearic acid) and products (1-octadecanol, ester, and heptadecane) was performed on a Perkin Elmer Auto System XL equipped with a flame ionization detector and a Thermo Scientific capillary column (id $=0.25 \mathrm{~mm}$; length $=15 \mathrm{~m}$; and od = $0.25 \mu \mathrm{m})$. It was operated under following conditions: injector and detector temperatures $\left(250{ }^{\circ} \mathrm{C}\right)$; air flow $(450 \mathrm{~mL} / \mathrm{min}) ; \mathrm{H}_{2}$ flow $(45$ $\mathrm{mL} / \mathrm{min}) ; \mathrm{N}_{2}$ flow $(14 \mathrm{~mL} / \mathrm{min})$; and split ratio of 50:1. Temperature column has set gradually into two steps (first: $100-220^{\circ} \mathrm{C}$ (ramping of 20 ${ }^{\circ} \mathrm{C} / \mathrm{min}$ ) and second: $220-300{ }^{\circ} \mathrm{C}$ (ramping of 18 ${ }^{\circ} \mathrm{C} / \mathrm{min}$ ). Gas chromatography-mass spectrometry (GC-MS) was performed on a a Shimadzu GC-17B equipped with a thermal conductivity detector and an RT- $\beta$ DEXsm capillary column. The products were confirmed 
by a comparison of their GC retention time, mass spectra with those of authentic samples. The conversion, yield and selectivity of the products were calculated according to the following equations:

$$
\begin{aligned}
& \text { Conversion }=\frac{F_{0}-F_{t}}{F_{0}} \times 100 \% \\
& \text { Yield }=\frac{\text { mol product }}{\Delta F} \times 100 \% \\
& \text { Selectivity }=\frac{\text { mol product }}{\text { total mol product }} \times 100 \%
\end{aligned}
$$

where, $F_{0}$ is the introduced mol reactant (stearic acid), $F_{t}$ is the remaining mol reactant, and $\Delta F$ is the consumed mol reactant (introduced mol reactant-remained mol reactant), which are all obtained from GC analysis using an internal standard technique.

\section{Results and Discussion}

\subsection{Catalyst characterization}

The $\mathrm{N}_{2}$-adsorption/desorption of microporous carbon (C) support and the synthe-
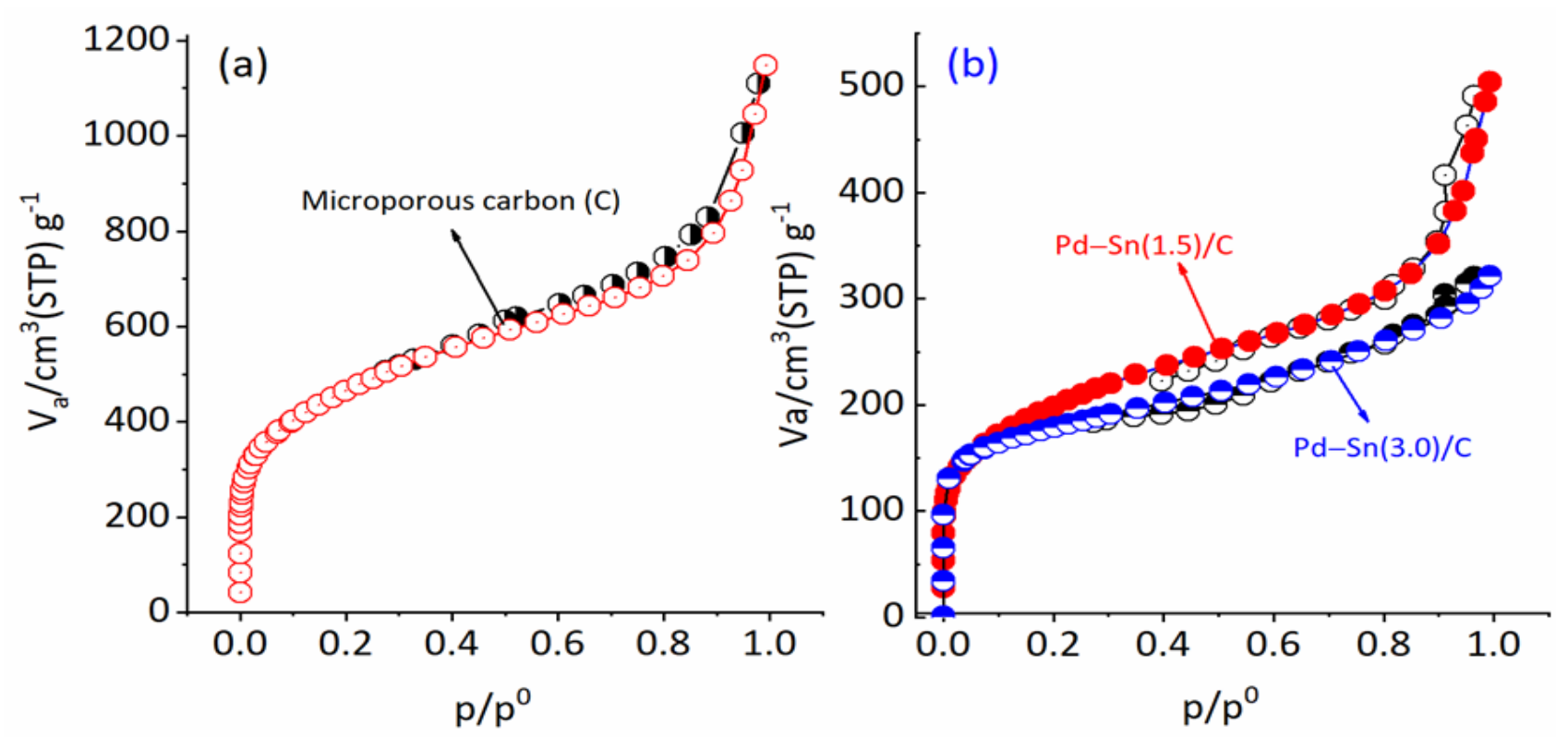

Figure 2. $\mathrm{N}_{2}$-adsorption/desorption profiles of (a) microporous carbon (C) and (b) the synthesized $\mathrm{Pd}-\mathrm{Sn}(3.0) / \mathrm{C}$ and $\mathrm{Pd}-\mathrm{Sn}(1.5) / \mathrm{C}$ catalysts after reduction with $\mathrm{H}_{2}$ at $400{ }^{\circ} \mathrm{C}$ for $3 \mathrm{~h}$.
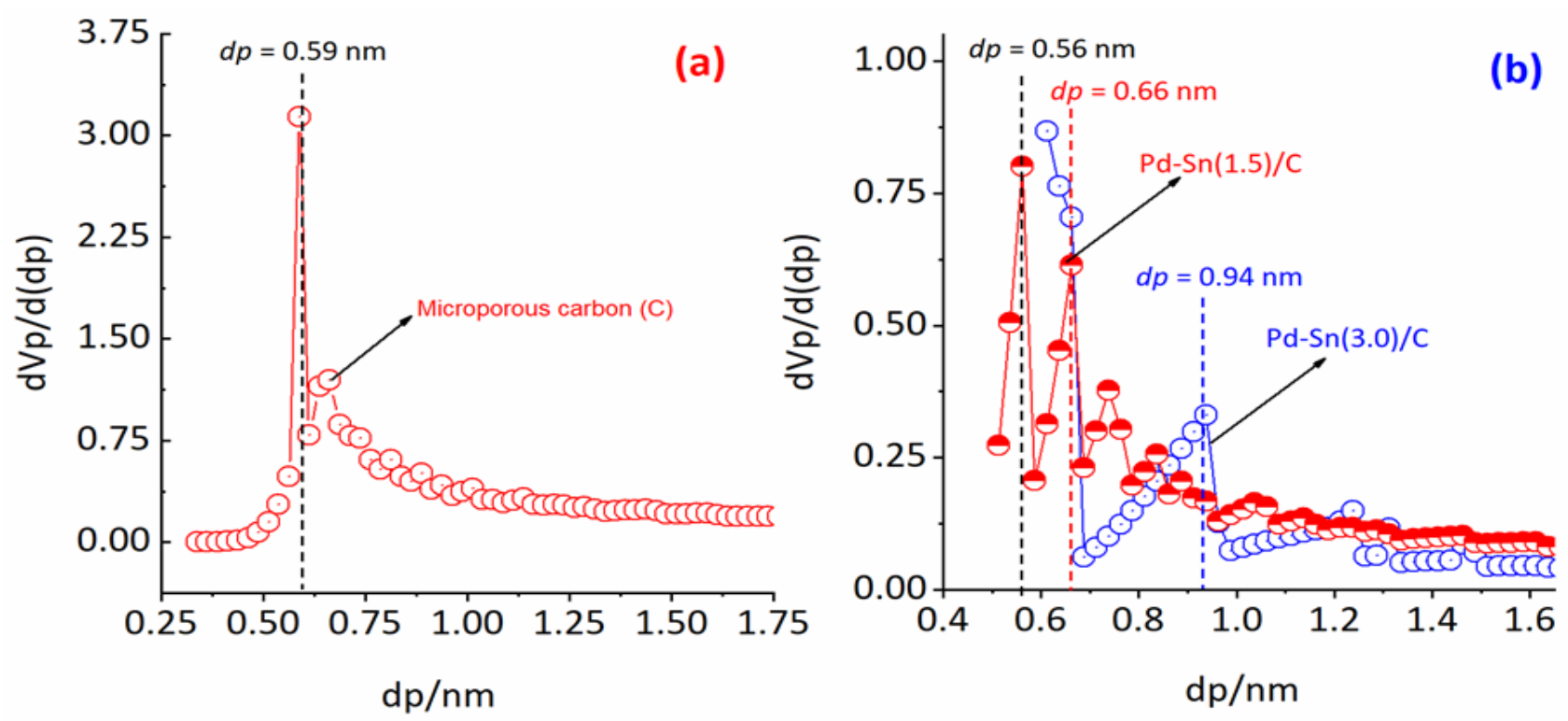

Figure 3. Pore distribution of (a) microporous carbon (C) and (b) the synthesized bimetallic $\mathrm{Pd}-\mathrm{Sn}(3.0) / \mathrm{C}$ and $\mathrm{Pd}-\mathrm{Sn}(1.5) / \mathrm{C}$ catalysts after reduction with $\mathrm{H}_{2}$ at $400{ }^{\circ} \mathrm{C}$ catalysts using $\mathrm{HK}$ approach. 
sized bimetallic $\mathrm{Pd}-\mathrm{Sn}(3.0) / \mathrm{C}$ and $\mathrm{Pd}-\mathrm{Sn}(1.5) / \mathrm{C}$ catalysts was performed and the profiles are shown in Figure 2. The hysteresis loop of adsorption/desorption of both the synthesized $\mathrm{Pd}-\mathrm{Sn}(3.0) / \mathrm{C}$ and $\mathrm{Pd}-\mathrm{Sn}(1.5) / \mathrm{C}$ samples show a very similar to that of former microporous carbon support, suggesting that there is no significant change of the pore structure of catalyst support during the introducing $\mathrm{Pd}$ and $\mathrm{Sn}$ metals or thermal activation using $\mathrm{N}_{2}$ or $\mathrm{H}_{2}$ at 400 ${ }^{\circ} \mathrm{C}$. It has been reported that carbon support has high thermal and chemical stability at the range of $300-500{ }^{\circ} \mathrm{C}$ under $\mathrm{H}_{2}$ or $\mathrm{N}_{2}$ atmosphere $[31,46]$.

To determine the pore size distribution of microporous carbon $\mathrm{C}$ support and the synthesized catalysts, the plot of volume of adsorbed$\mathrm{N}_{2}$ versus pore distribution using HorvathKawazoe (HK) approach were performed as shown in Figure 3. As expected, the microporous carbon (C) support shows the microstructure of carbon with narrow pore size distribution of 0.59-0.66 nm (Figure 3a). After introduction of $\mathrm{Pd}-\mathrm{Sn}$, the shift of pore size distribution at $\geq 0.66 \mathrm{~nm}$ for after reduction with $\mathrm{H}_{2}$ at $400{ }^{\circ} \mathrm{C}$ and recovered samples are clearly observed (Figure 3b). However, there is no clear evidence for the shift of pore size distribution towards small pore sizes or big pore sizes after introducing the $\mathrm{Pd}-\mathrm{Sn}$ species or thermal activation using $\mathrm{N}_{2}$ or $\mathrm{H}_{2}$ at $400{ }^{\circ} \mathrm{C}$.

To confirm the importance of catalyst acidity, ammonia-temperature programmed desorption $\left(\mathrm{NH}_{3}\right.$-TPD) was performed (Figure 4) and the results are summarized in Table 1 . Microporous carbon and commercial $5 \mathrm{wt} \% \mathrm{Pd} / \mathrm{C}$ have total acidity of $0.019 \mathrm{mmol.g} \mathrm{g}^{-1}$ and 0.103 mmol.g ${ }^{-1}$, respectively which mainly consisted
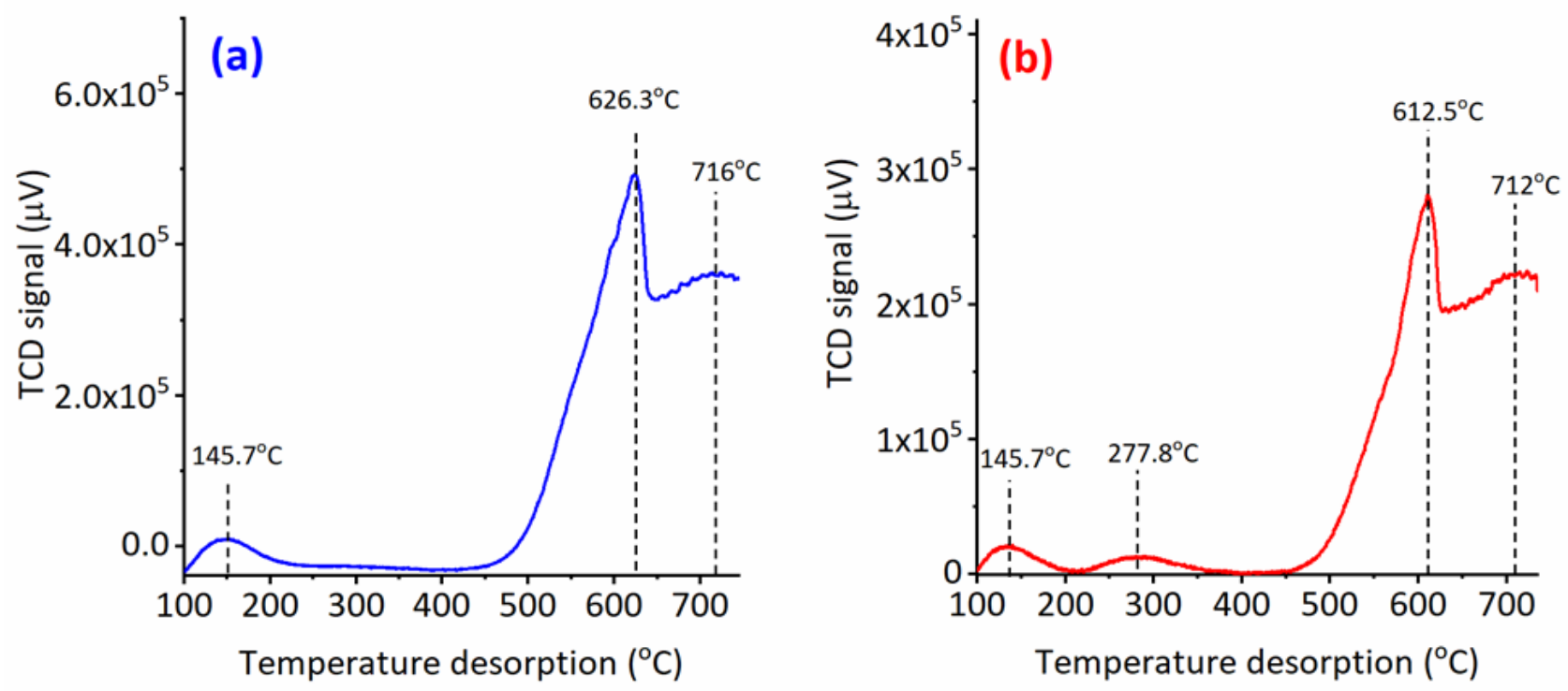

Figure 4. Typical ammonia-temperature programmed desorption $\left(\mathrm{NH}_{3}\right.$-TPD) profiles of the synthesized (a) $\mathrm{Pd}-\mathrm{Sn}(3.0) / \mathrm{C}$ and (b) $\mathrm{Pd}-\mathrm{Sn}(1.5) / \mathrm{C}$ catalysts after reduction with $\mathrm{H}_{2}$ at $400{ }^{\circ} \mathrm{C}$.

Table 1. Physicochemical properties of the synthesized supported bimetallic $\mathrm{Pd}-\mathrm{Sn}(1.5) / \mathrm{C}$ catalysts.

\begin{tabular}{|c|c|c|c|c|c|c|c|c|c|}
\hline \multirow{2}{*}{ Entry } & \multirow{2}{*}{ Catalysts $^{a}$} & \multicolumn{2}{|c|}{$\begin{array}{c}\mathrm{LA}^{a} \\
\left(\mathrm{mmol} \cdot \mathrm{g}^{-1}\right) \\
\end{array}$} & \multirow{2}{*}{$\begin{array}{c}S_{B E T^{b}} \\
\left(\mathrm{~m}^{2} \cdot \mathrm{g}^{-1}\right)\end{array}$} & \multirow{2}{*}{$\begin{array}{l}\text { Pore vol. }{ }^{b} \\
\left(\mathrm{~cm}^{3} \cdot \mathrm{g}^{-1}\right)\end{array}$} & \multirow{2}{*}{$\begin{array}{c}\mathrm{PSD}^{b} \\
(\mathrm{~nm})\end{array}$} & \multirow{2}{*}{$\begin{array}{l}\mathrm{H}_{2} \text { uptake }^{c} \\
\left(\mathrm{mmol}^{-\mathrm{g}^{-1}}\right)\end{array}$} & \multirow{2}{*}{$\begin{array}{c}\text { Total acid } \\
\text { sites }^{d} \\
\left(\mathrm{mmol.g}^{-1}\right)\end{array}$} & \multirow{2}{*}{$\begin{array}{c}D^{e} \\
(\mathrm{~nm})\end{array}$} \\
\hline & & $\mathrm{Pd}$ & $\mathrm{Sn}$ & & & & & & \\
\hline 1 & Micro. carbon (C) & - & - & 815 & 1.762 & 0.59 & NA & $0.019 f$ & NA \\
\hline 2 & $5 \mathrm{wt} \% \mathrm{Pd} / \mathrm{C}$ & 0.498 & - & 936 & 0.431 & 0.98 & 25.3 & 0.103 & $\mathrm{NA}$ \\
\hline 3 & $\mathrm{Pd}-\mathrm{Sn}(3.0) / \mathrm{C}$ & 0.458 & 0.154 & 637 & 0.49 & 0.94 & 26.7 & 0.338 & 8.1 \\
\hline 4 & $\mathrm{Pd}-\mathrm{Sn}(1.5) / \mathrm{C}$ & 0.461 & 0.295 & 719 & 0.769 & 0.66 & 19.2 & 0.418 & 9.9 \\
\hline $5^{g}$ & $\mathrm{Pd}-\mathrm{Sn}(1.5) / \mathrm{C}$ rec. & 0.461 & 0.295 & 677 & 0.551 & 0.56 & - & - & \\
\hline
\end{tabular}

${ }^{a}$ Values in the parentheses are the Pd/Sn molar ratios determined by ICP-OES; LA = loading amount. ${ }^{b}$ Determined by $\mathrm{N}_{2}$ adsorption at $-196{ }^{\circ} \mathrm{C}$; pore sizes distribution (PSD) was calculated by using Horvath-Kawazoe's approach. ${ }^{c}$ Based upon the total $\mathrm{H}_{2}$ uptake at $0{ }^{\circ} \mathrm{C}$ (after corrections for physical and chemical adsorption). ${ }^{d}$ Total acid sites were derived from $\mathrm{NH}_{3}$-TPD data. ${ }^{e}$ Average $\mathrm{Pd}(111)$ or Pd-Sn crystallite sizes were calculated according to the Scherrer equation. $f$ Microporous carbon was calcined at $573{ }^{\circ} \mathrm{C}$ for $4 \mathrm{~h}$ under $\mathrm{N}_{2}$ atmosphere [47]. $g$ Recovered $\mathrm{Pd}-\mathrm{Sn}(1.5) / \mathrm{C}$ after the first reaction run. NA = not available. 
of weak acidity (entries 1 and 2). After introducing Sn loading amount of 0.0 .154 mmol.g ${ }^{-1}$ and $0.295 \mathrm{mmol} . \mathrm{g}^{-1}$, the total acidity of $\mathrm{Pd}-\mathrm{Sn}(3.0) / \mathrm{C}$ (Figure 4a) and $\mathrm{Pd}-\mathrm{Sn}(1.5) / \mathrm{C}$
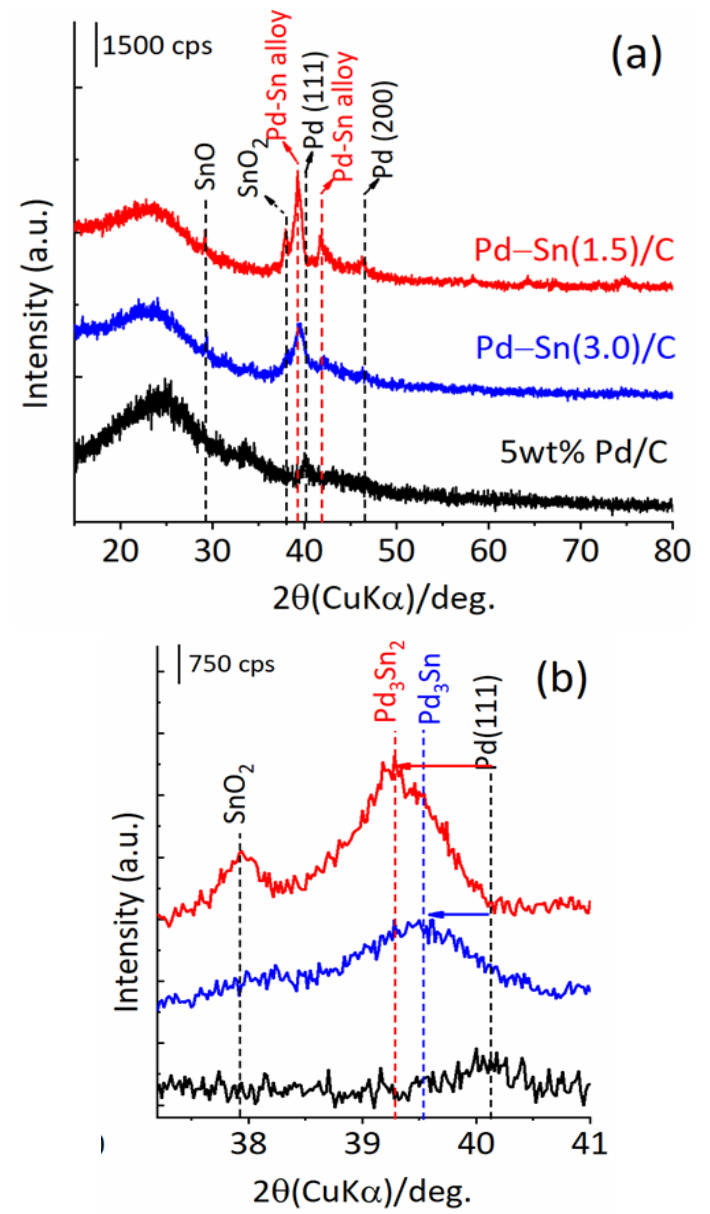

Figure 5. (a) XRD patterns of commercial $5 \mathrm{wt} \%$ $\mathrm{Pd} / \mathrm{C}$ and the synthesized bimetallic $\mathrm{Pd}-\mathrm{Sn}(3.0) / \mathrm{C}$ and $\mathrm{Pd}-\mathrm{Sn}(1.5) / \mathrm{C}$ after reduction with $\mathrm{H}_{2}$ at 400 ${ }^{\circ} \mathrm{C}$ for $3 \mathrm{~h}$. (b) Selected diffraction peaks $(2 \theta=$ $37-41^{\circ}$ ) of each samples.
(Figure 4b) remarkable increased to 0.338 mmol.g ${ }^{-1}$ and 0.418 mmol.g ${ }^{-1}$, respectively (entries 3-4). There was a significant different in the total acidity of $\mathrm{Pd}-\mathrm{Sn} / \mathrm{C}$ with different Sn loading amounts, suggesting that the effect of total acidity may be played important role during the selective hydrogenation of stearic acid to 1-octadecanol (stearyl alcohol) under the current operating conditions.

Figure 5 shows the XRD pattern of commercial $5 \mathrm{wt} \% \quad \mathrm{Pd} / \mathrm{C}$, pre-reduced bimetallic $\mathrm{Pd}-\mathrm{Sn}(3.0) / \mathrm{C}$ and $\mathrm{Pd}-\mathrm{Sn}(1.5) / \mathrm{C}$ catalysts. The commercial $5 \mathrm{wt} \% \mathrm{Pd} / \mathrm{C}$ exhibited a typical diffraction peak of metallic $\operatorname{Pd}(111)$ at $2 \theta=40.18^{\circ}$ (Figure 5(a)). In the case of $\mathrm{Pd}-\mathrm{Sn}(3.0) / \mathrm{C}$ catalyst, the typical diffraction peaks at $2 \theta=29.4^{\circ}$. $39.5^{\circ}, 42.1^{\circ}$, and $46.5^{\circ}$ were clearly observed, which can be attributed to the tin oxide $(\mathrm{SnO})$ and metallic $\operatorname{Pd}(111)$ and $\operatorname{Pd}(200)$ phases (JCPDS\#05-0681), respectively [48]. A significant shifting the diffraction at $2 \theta=40.2^{\circ}$ of former $\mathrm{Pd} / \mathrm{C}$ toward lower angle in $\mathrm{Pd}-\mathrm{Sn}(3.0) / \mathrm{C}$ $\left(2 \theta=39.5^{\circ}\right)$ can be suggested due to the modified surface structure of $\operatorname{Pd}(111)$ in the presence of Sn promoter either to form surface bimetallic or alloy Pd-Sn (Figure 5b) [49,50]. Further increasing the Sn loading amount (Sn $=0.295 \mathrm{mmol})$ to form $\mathrm{Pd}-\mathrm{Sn}(1.5) / \mathrm{C}$ catalyst, two diffraction peaks of Pd-Sn alloy at $2 \theta=$ $39.3^{\circ}$ and $41.8^{\circ}$ which assigned as Pd-Sn alloy phases are intensified. By using the Scherrer`s equation, the average crystallite sizes of $\mathrm{Pd}(111)$ in $\mathrm{Pd}-\mathrm{Sn}(3.0) / \mathrm{C}$ and $\mathrm{Pd}-\mathrm{Sn}(1.5) / \mathrm{C}$ were $8.1 \mathrm{~nm}$ and $9.9 \mathrm{~nm}$ (Table 1), respectively at around of the overlapped diffraction peaks of $\operatorname{Pd}(111)$ and $\mathrm{Pd}-\mathrm{Sn}$ alloy phase (Figure 5a-b). A small new peak was also observed at $2 \theta=$ $37.9^{\circ}$, which can be associated to $\mathrm{SnO}_{2}$ species (JCPD\#29-1484) both in the in $\mathrm{Pd}-\mathrm{Sn}(3.0) / \mathrm{C}$ and $\mathrm{Pd}-\mathrm{Sn}(1.5) / \mathrm{C}$ samples (Figure $5 \mathrm{a}$ ).

Table 2. Results of solvent screening for hydrogenation of stearic acid using bimetallic $\mathrm{Pd}-\mathrm{Sn}(1.5) / \mathrm{C}$ catalyst.

\begin{tabular}{|c|c|c|c|c|c|}
\hline \multirow{2}{*}{ Entry } & \multirow{2}{*}{ Solvent } & \multirow{2}{*}{ Conversion $^{a}(\%)$} & \multicolumn{3}{|c|}{ Yield $^{b}(\%)$} \\
\hline & & & 1-Octadecanol & Ester & Others \\
\hline 1 & Methanol & 56.3 & 1.7 & 50.6 & 4 \\
\hline 2 & Ethanol & 67.4 & 3.2 & 59 & 5.2 \\
\hline 3 & 2-Propanol & 87.2 & 9.1 & 53 & 25.1 \\
\hline 4 & $\mathrm{H}_{2} \mathrm{O}$ & 17 & 7.1 & $<0.1$ & 9.9 \\
\hline 5 & 1,4-Dioxane & 21.7 & 11.5 & $<0.1$ & 10.2 \\
\hline 6 & Ethanol $/ \mathrm{H}_{2} \mathrm{O}(4.5: 0.5 \mathrm{v} / \mathrm{v})$ & 89 & 13.7 & 61.3 & 14 \\
\hline 7 & 1,4-Dioxane $/ \mathrm{H}_{2} \mathrm{O}(4.5: 0.5 \mathrm{v} / \mathrm{v})$ & 49.2 & 21.2 & $<0.1$ & 28 \\
\hline 8 & 2-Propanol/ $/ \mathrm{H}_{2} \mathrm{O}(4.5: 0.5 \mathrm{v} / \mathrm{v})$ & 84.3 & 32.2 & 32.1 & 20 \\
\hline
\end{tabular}

Reaction conditions: catalyst $(0.05 \mathrm{~g})$; stearic acid $(0.2844 \mathrm{~g} ; 1.0 \mathrm{mmol})$; solvent $(5.0 \mathrm{ml})$; temperature $240{ }^{\circ} \mathrm{C}$; initial $\mathrm{H}_{2}$ pressure $(3.0 \mathrm{MPa})$; reaction time $(7 \mathrm{~h})$. ${ }^{a}$ Conversion was determined by $\mathrm{GC}$ using an internal standard technique. ${ }^{b}$ Yields were

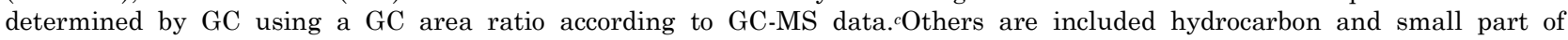
unidentified products based on the GC-MS analyses data. 


\subsection{Catalytic Reaction Testing}

\subsubsection{Screening of solvent}

In the first set experiment of catalytic reactions, the effect of solvent used on the conversion and yield in the hydrogenation of stearic acid over $\mathrm{Pd}-\mathrm{Sn}(1.5) / \mathrm{C}$ catalyst was studied and the results are summarized in Table 2 . In alcoholic solvents (e.g. methanol, ethanol, and 2-propanol), as expected, the conversion of stearic acid was around $56-87 \%$ with very low yield of 1-octadecanol (1.7-9.1\%), whereas the yield of stearic ester was obtained (entries 1-3). By using protic polar solvent $\left(\mathrm{H}_{2} \mathrm{O}\right)$ or aprotic polar solvent (1,4-dioxane), the yields of 1 -octadecanol were $7.1 \%$ and $11.5 \%$, respectively (entries 4 and 5). The utilization of 1,4dioxane solvent seems to be promising as indicated by relatively higher yield of 1-octadecanol than the others, however, 1,4-dioxane is relatively more expensive and somehow less environmentally friendly than that of alcoholic or water solvent.

Therefore, the mixture of $\mathrm{H}_{2} \mathrm{O}$ and alcoholic as well as 1,4-dioxane solvents were examined for the hydrogenation of stearic acid to 1-octadecanol under the same reaction conditions. In ethanol/ $\mathrm{H}_{2} \mathrm{O} \quad(4.5: 0.5 \quad \mathrm{v} / \mathrm{v})$ and 1,4-dioxane $/ \mathrm{H}_{2} \mathrm{O}(4.5: 0.5 \mathrm{v} / \mathrm{v})$ solvents, the yield of 1-octadecanol slightly increased to $13.7 \%$ and $21.3 \%$, respectively (entries 6 and 7 ). The highest yield of 1-octadecanol (32.2\%) was obtain in 2-propanol/ $/ \mathrm{H}_{2} \mathrm{O}(4.5: 0.5 \mathrm{v} / \mathrm{v})$ solvent at $84.3 \%$ conversion (entry 8), therefore, the mixture 2-propanol/ $/ \mathrm{H}_{2} \mathrm{O}$ will be applied as a solvent for further catalytic reaction using various cata- lysts (screening of catalyst) and optimization of reaction parameters such as temperature, initial $\mathrm{H}_{2}$ pressure, time profiles, and reusability test.

\subsubsection{Screening of catalyst}

The catalytic reaction of stearic acid using various palladium-based catalysts were performed and the results are summarized in Table 3. By using a commercial $\mathrm{Pd} / \mathrm{C}(\mathrm{Pd}=5 \mathrm{wt} \%)$ catalyst, a $79.3 \%$ conversion of stearic acid was obtained and produced only $7.1 \%$ yield of 1-octandecanol with side-products of ester (16.5\%) and others mainly consisted of $\mathrm{C}_{17}-\mathrm{C}_{18}$ aliphatic hydrocarbon (55.7\%) (entry 1). A remarkably high yield of $\mathrm{C}_{17}-\mathrm{C}_{18}$ aliphatic hydrocarbon was obtained, suggesting the deoxygenation (decarbonylation or decarboxylation) reaction of stearic acid under current operating reaction was occurred predominantly. Lamb et al. suggested that liquid deoxygenation of $\mathrm{C}_{18}$ free fatty acid primarily occured in the presence of a $5 \mathrm{wt} \%$ $\mathrm{Pd} / \mathrm{C}$ catalyst, led to high yield of heptadecane [37].

After introducing $\mathrm{Sn}=0.1542 \mathrm{mmol}$ to form $\mathrm{Pd}-\mathrm{Sn}(3.0) / \mathrm{C}(3.0$ is $\mathrm{Pd} / \mathrm{Sn}$ molar ratio; $\mathrm{Pd}$ is $5 \mathrm{wt} \%$; Sn $=0.1542 \mathrm{mmol}$ ) catalyst, stearic acid conversion slightly increased to $87.0 \%$ and the yield of 1-octadecanol remarkably increased to $27.4 \%$ (approximately 4 -fold to $\mathrm{Pd} / \mathrm{C}$ catalyst). However, yield of isopropyl stearate is remained high $(29.3 \%)$, while other product reduced significantly to $30.3 \%$ (entry 2). A remarkable increase the yield of of

Table 3. Results of catalyst screening for hydrogenation of stearic acid to 1-octadecanol.

\begin{tabular}{|c|c|c|c|c|c|}
\hline \multirow{2}{*}{ Entry } & \multirow{2}{*}{ Catalyst $^{a}$} & \multirow{2}{*}{ Conversion $^{b}(\%)$} & \multicolumn{3}{|c|}{ Yield $c(\%)^{2}$} \\
\hline & & & 1-Octadecanol & Isopropyl stearate & Others $^{d}$ \\
\hline 1 & $\mathrm{Pd} / \mathrm{C}^{e}$ & 79.3 & 7.1 & 16.5 & 55.7 \\
\hline 2 & $\mathrm{Pd}-\mathrm{Sn}(3.0) / \mathrm{C}$ & 87 & 27.4 & 29.3 & 30.3 \\
\hline 3 & $\mathrm{Pd}-\mathrm{Sn}(1.5) / \mathrm{C}$ & 89.3 & 56.2 & 23.1 & 10 \\
\hline 4 & $\mathrm{Pd}-\mathrm{Sn}(1.0) / \mathrm{C}$ & 63.8 & 28.2 & 25.6 & 10 \\
\hline $5^{f}$ & $\mathrm{Pd}-\mathrm{Sn}(1.5) / \mathrm{C}$ & 73.5 & 49.7 & 17.4 & 6.4 \\
\hline 6 & $\mathrm{Pd}-\mathrm{Sn}(1.5) / \mathrm{TiO}_{2}$ & 77.9 & 32.8 & 32.2 & 2.9 \\
\hline 7 & $\mathrm{Pd}-\mathrm{Sn}(1.5) / \mathrm{Nb}_{2} \mathrm{O}_{5}$ & 79.2 & 23.4 & 52.4 & 3.4 \\
\hline 8 & $\mathrm{Pd}-\mathrm{Sn}(1.5) / \mathrm{g}-\mathrm{Al}_{2} \mathrm{O}_{3}$ & 84.4 & 32.5 & 45.3 & 6.6 \\
\hline 9 & Pd-Sn(1.5)/Y-Zeolite & 46 & 11.7 & 29 & 5.3 \\
\hline 10 & Pd-Sn(1.5)/HZSM-5 & 71.7 & 6.5 & 59.4 & 5.8 \\
\hline
\end{tabular}

${ }^{a}$ The value in the parenthesis is $\mathrm{Pd} / \mathrm{Sn}$ molar ratio; determined by ICP-OES. Reaction conditions: catalyst (0.05 g); stearic acid $(0.2844 \mathrm{~g} ; 1.0 \mathrm{mmol})$; solvent (2-propanol $\left./ \mathrm{H}_{2} \mathrm{O} ; 5.0 \mathrm{ml} ; 4.0: 1.0 \mathrm{v} / \mathrm{v}\right)$; temperature $240{ }^{\circ} \mathrm{C}$; initial $\mathrm{H}_{2}$ pressure $(3.0 \mathrm{MPa})$; reaction time $(7 \mathrm{~h}) .{ }^{b}$ Conversion was determined by GC using an internal standard technique. ${ }^{c}$ Yields were determined by GC using GC area ratio according to GC-MS data. ${ }^{d}$ Others are included hydrocarbon and small part unidentified products using GC or GC-MS analyses. ${ }^{e}$ Commercially available $5 \mathrm{wt} \% \mathrm{Pd} / \mathrm{C}$. $f$ Reusability test of $\mathrm{Pd}-\mathrm{Sn}(1.5) / \mathrm{C}$ catalyst; recovered catalyst was reused directly without any further thermal treatment. 
1-octadecanol of $56.2 \%$ (approximately 8-fold compared to $\mathrm{Pd} / \mathrm{C}$ catalyst) at stearic acid conversion of $89.3 \%$ was obtained over $\mathrm{Pd}-\mathrm{Sn}(1.5) / \mathrm{C}$ catalyst (loading amount of $\mathrm{Sn}$ was $0.2947 \mathrm{mmol} ; \mathrm{Pd} / \mathrm{Sn}=1.5)$, while the yield of ester and others significantly diminished to $23.1 \%$ and $10 \%$, respectively (entry 3 ). The high yield of 1-octadecanol obtained over $\mathrm{Pd}-\mathrm{Sn}(1.5) / \mathrm{C}$ catalyst can be associated with the presence of bimetallic $\mathrm{Pd}-\mathrm{Sn}$ alloy phases as depicted by XRD patterns (Figure 5). We believe that our $\mathrm{Pd}-\mathrm{Sn}$ catalyst systems have a similar catalytic behaviour to that of $\mathrm{Ru}-\mathrm{Sn}$ systems as had been reported by Desphande et al. [25,26]. They concluded that the highest activity and selectivity are attributed to $\mathrm{Ru}^{0}$ sites interacting with $\mathrm{Sn}^{2+}$ or $\mathrm{Sn}^{4+}$ Lewis acid sites via oxygen, wherein the Lewis acid preferentially activates $\mathrm{C}=\mathrm{O}$ of the ester, facilitating hydrogen transfer from adjacent $\mathrm{Ru}-\mathrm{H}$ sites. Most recently, Luo et al. suggested that two types of sites: $(a) \mathrm{Ru}^{0}$ interacting with $\mathrm{Sn}^{2+}$ or $\mathrm{Sn}^{4+}$ via the oxygen; (b) nanocluster $\mathrm{Rn}_{3} \mathrm{Sn}_{7}$ alloy, wherein ruthenium as well as tin is present in zero oxidation state (this may be present in small quantities on the surface) [24]. Moreover, further incereasing the loading amount of $\mathrm{Sn}$ to $0.4613 \mathrm{mmol}(\mathrm{Pd}-\mathrm{Sn}(1.0) / \mathrm{C})$, stearic acid conversion significantly decreased to $63.8 \%$ as well as the yield of 1-octadecanol (28.2\%) (entry 4). The reusability test of $\mathrm{Pd}-\mathrm{Sn}(1.5) / \mathrm{C}$ catalyst was also performed and the results are also show in Table 3, entry 5 .

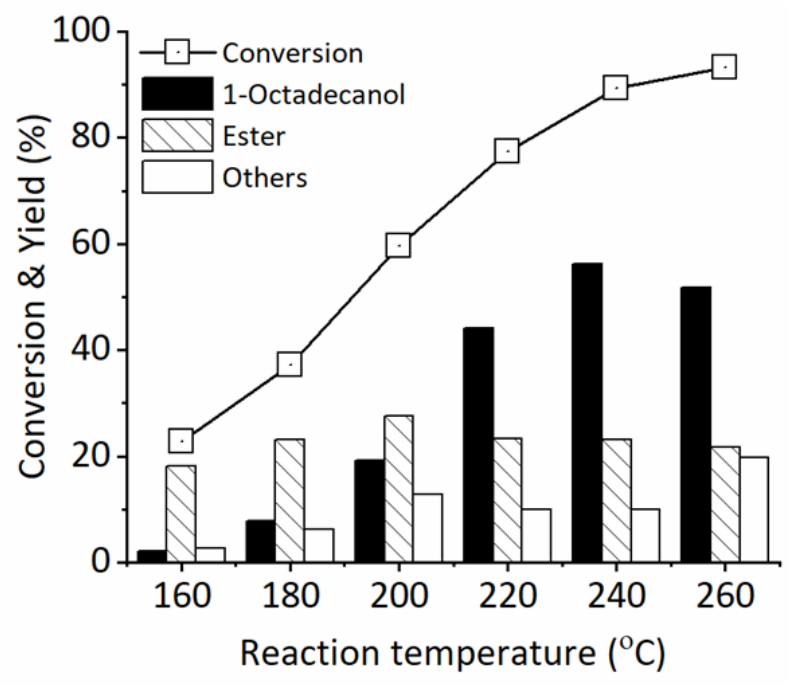

Figure 6. Effect of reaction temperature on conversion and yield in the hydrogenation of stearic acid using $\mathrm{Pd}-\mathrm{Sn}(1.5) / \mathrm{C}$ catalyst. Reaction conditions: catalyst $(0.05 \mathrm{~g})$; stearic acid $(0.2844 \mathrm{~g} ; 1.0 \mathrm{mmol})$; solvent (2propanol $/ \mathrm{H}_{2} \mathrm{O}(5.0 \mathrm{ml} ; 4.0: 1.0 \mathrm{v} / \mathrm{v})$; initial $\mathrm{H}_{2}$ pressure $(3.0 \mathrm{MPa})$; reaction time $(7 \mathrm{~h})$.
The conversion of stearic acid slightly decreased to $73.5 \%$ as well as the yield of 1-octadenaol (49.7\%), isopropyl stearate (17.4\%), and others (6.4\%) (entry 5). Results of $\mathrm{N}_{2}$-adsorption-desorption of the recovered $\mathrm{Pd}-\mathrm{Sn}(1.5) / \mathrm{C}$ showed that the $S_{\mathrm{BET}}$, pore volume, and pore size distribution (PSD) slightly decreased, indicating the hydrothermal reaction conditions may affect the structure of catalyst (Table 1, entry 5).

To complete the catalyst screening tests, various supported $\mathrm{Pd}-\mathrm{Sn}$ catalysts were synthesized and applied for the same catalytic reaction. $\mathrm{TiO}_{2}-, \mathrm{Nb}_{2} \mathrm{O}_{5}-$, and $\gamma-\mathrm{Al}_{2} \mathrm{O}_{3}-$ supported $\mathrm{Pd}-\mathrm{Sn}$ catalysts demonstrated similar catalytic activity (78-84\% conversion of stearic acid) and produced $23-32 \%$ yield of 1-octandecanol under the same reaction conditions (entries 6-8). The supported bimetallic nanoparticles could be synergically catalyzed the hydrogenation of fatty acid to alcohols as reported by Slowing et al. [51], who applied copper oxide-iron oxide on mesoporous silica for stearic acid hydrogenation under moderate conditions. They claimed that in situ reduction of copper oxide to its metallic form thereby activates hydrogen, which can be spilled over to the iron oxide where stearic acid bind and are selectively reduced to 1-octadecanol [51]. Further optimization of reaction parameters using those catalysts are under investigation and will be reported in the upcoming manuscript. Moreover, $\mathrm{Pd}-\mathrm{Sn}$ supported on zeolite matrixes, such as Y-zeolite and HZSM-5 catalysts, were also examined for the hydrogenation of stearic acid under the same reaction conditions. However, the results are unsatisfied in the terms of stearic acid conversion and yield of 1octadecanol (entries 9-10). Therefore, it can be concluded that $\mathrm{Pd}-\mathrm{Sn}(1.5) / \mathrm{C}$ is the best catalyst for stearic acid hydrogenation and it will be examined for further evaluation of reaction parameter.

\subsubsection{Effect of reaction temperature}

The effect of reaction temperature on conversion and yield in the hydrogenation of stearic acid using $\mathrm{Pd}-\mathrm{Sn}(1.5) / \mathrm{C}$ catalyst was examined at the range of $160-260{ }^{\circ} \mathrm{C}$ and the results are shown in Figure 6 . The reaction temperature notably affected the catalytic activity and product distribution. Stearic acid conversion was only $22.6 \%$ at $160{ }^{\circ} \mathrm{C}$, yielding approximately $2.1 \% \quad 1$-octadecanol, $18.1 \%$ ester (isopropyl stearate) and other side-products were mainly $\mathrm{C}_{36}$ compounds. Remarkably, both 
the conversion of stearic acid (89.3\%) and yield of 1-octadecanol (56.2\%) immensely increased when the reaction temperature was increased to $240{ }^{\circ} \mathrm{C}$. Further increasing the reaction temperature to $260{ }^{\circ} \mathrm{C}$ led to a $93.2 \%$ conversion of stearic acid, while the yield of 1-octadecanol slightly decreased to $51.7 \%$. It should be noted that the yield of ester (isopropyl stearate) gradually increased as the reaction temperature increased to $200{ }^{\circ} \mathrm{C}$, then decreased smoothly at reaction temperature over $220{ }^{\circ} \mathrm{C}$. On the other hand, other products significantly increased at $260{ }^{\circ} \mathrm{C}$, which can be rationalized due to the further hydrogenation reaction of formed ester to 1-octadecanol or dehydration-hydrogenation of 1-octadecanol to hydrocarbon (e.g., octadecane). Further reactions would be occurred at high reaction temperature as indicated by Wang et al., who reported the hydrogenation of stearic acid to 1-octadecanol using bimetallic $\mathrm{Ni}-\mathrm{Fe}$ alloy $250-270{ }^{\circ} \mathrm{C}$ [52]. Therefore, we concluded that the optimized reaction temperature for the hydrogenation of stearic acid using $\mathrm{Pd}-\mathrm{Sn}(1.5) / \mathrm{C}$ catalyst is $240^{\circ} \mathrm{C}$, which it will be used for evaluation of initial $\mathrm{H}_{2}$ pressure and time profiles.

\subsubsection{Effect of initial $\mathrm{H}_{2}$ pressure}

The effect of initial $\mathrm{H}_{2}$ pressure on the conversion and yield in the hydrogenation of stearic acid using $\mathrm{Pd}-\mathrm{Sn}(1.5) / \mathrm{C}$ catalyst at $240{ }^{\circ} \mathrm{C}$ for $7 \mathrm{~h}$ was investigated and the results are shown in Figure 7. The conversion of stearic acid increased slowly when the initial $\mathrm{H}_{2}$ pressure increased up to $3.0 \mathrm{MPa}$, yielding the highest1-octadecanol $(56.2 \%)$ at $89.3 \%$ stearic acid conversion. When the initial $\mathrm{H}_{2}$ pressure was furtherly increased to $4.0 \mathrm{MPa}$, stearic acid conversion was $90.3 \%$ and yielded $52.7 \%$ 1-octadecanol. It should be noted that the increase of initial $\mathrm{H}_{2}$ pressure greatly affected to the decrease of intermediate ester product, leading to high yield of 1-octadecanol (Figure 7(a)). Therefore, it can be concluded that the optimized initial $\mathrm{H}_{2}$ pressure would be 3.0 $\mathrm{MPa}$. Turn over frequency (TOF) value was used to evaluate the intrinsic activity of $\mathrm{Pd}-\mathrm{Sn}(1.5) / \mathrm{C}$ catalyst with keeping the conversion of stearic acid lower than 20\%. A linear relationship between $\ln$ (TOF) and $\ln$ initial $\mathrm{H}_{2}$ pressure could be obtained, and the slope represnted the reaction order with respect to hydrogen pressure (Figure 7(b)). The reaction order to hydrogen over $\mathrm{Pd}-\mathrm{Sn}(1.5) / \mathrm{C}$ catalyst was calculated to be 0.479 , indicated that high accessibility of hydrogen and promoted the reaction rate of stearic conversion.

\subsubsection{Time profiles}

The kinetic study of stearic acid hydrogenation was carried out using $\mathrm{Pd}-\mathrm{Sn}(1.5) / \mathrm{C}$ catalyst at $240{ }^{\circ} \mathrm{C}, 3.0 \mathrm{MPa}$ of $\mathrm{H}_{2}$, in 2propanol $/ \mathrm{H}_{2} \mathrm{O}$ solvent to understand the
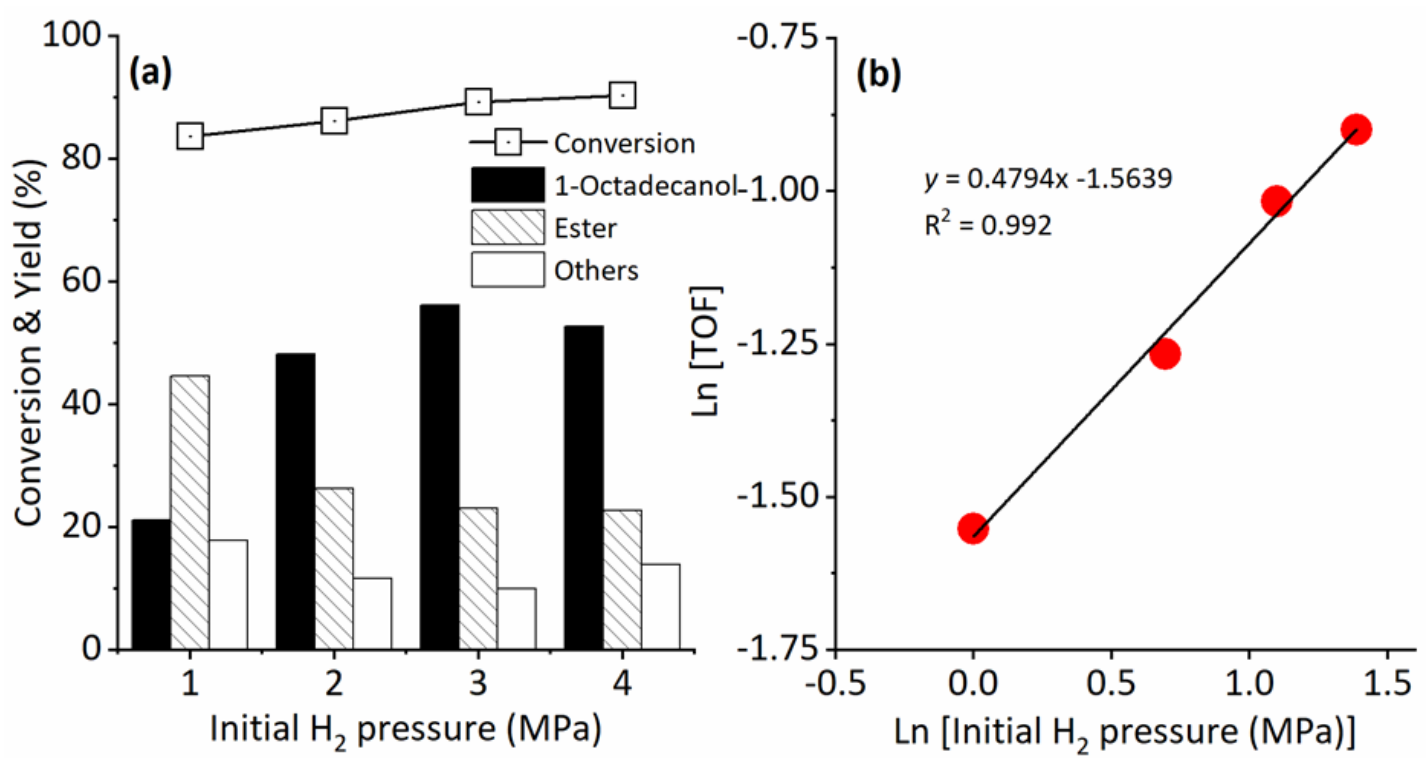

Figure 7. (a) Effect of initial $\mathrm{H}_{2}$ pressure on conversion and yield in the hydrogenation of stearic acid using Pd-Sn(1.5)/C catalyst. Reaction conditions: catalyst (0.05 g); stearic acid (0.2844 g; $1.0 \mathrm{mmol})$; solvent (2-propanol/ $\mathrm{H}_{2} \mathrm{O}(5.0 \mathrm{~mL} ; 4.0: 1.0 \mathrm{v} / \mathrm{v})$; reaction temperature $\left(240{ }^{\circ} \mathrm{C}\right)$; reaction time $(7 \mathrm{~h})$. (b) the effect of initial $\mathrm{H}_{2}$ pressure on the rate of reaction on $\mathrm{Pd}-\mathrm{Sn}(1.5) / \mathrm{C}$ catalyst at low level stearic conversion $(\sim 20 \%)$. 
conversion of stearic acid and the evolution of product formation and the results are shown in Figure 8.

Stearic acid conversion was elevated smoothly and achieved $100 \%$ conversion when the reaction time was $13 \mathrm{~h}$, yielding $73.2 \% 1$ octadecanol, $15.3 \%$ ester (isopropyl stearat), and $11.5 \%$ others. The yield of isopropyl stearat slightly increased to $23.1 \%$ at a reaction time of $7 \mathrm{~h}$, suggesting that the formation of isopropyl stearat was one of important intermediate then followed by its hydrogenation to form 1octadecanol. To confirm this suggestion, the catalytic reaction of typical methyl stearate was performed under the same reaction conditions. A $65.4 \%$ conversion of methyl stearate and $37.6 \%$ yield of 1 -octadecanol were obtained at $240{ }^{\circ} \mathrm{C}, 3.0 \mathrm{MPa} \mathrm{H}_{2}$ and after $7 \mathrm{~h}$.

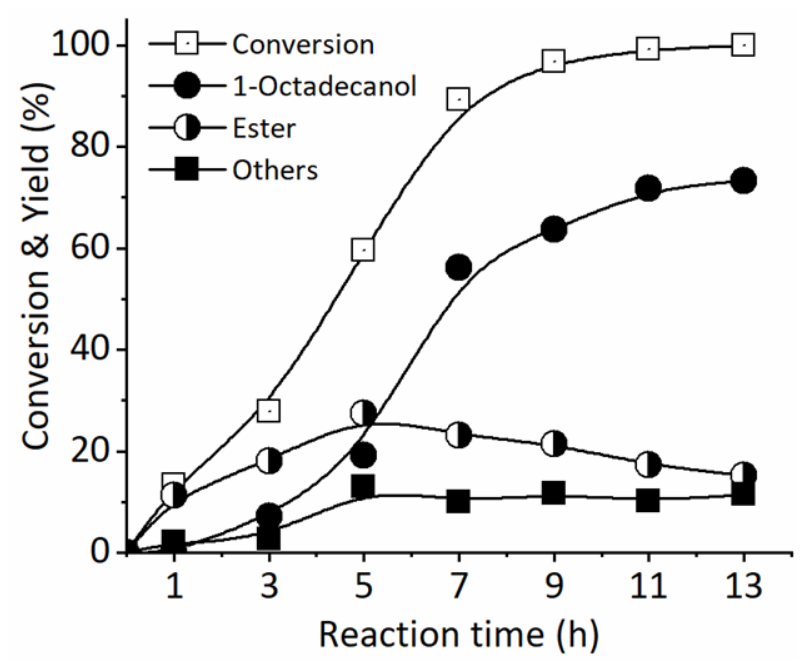

Figure 8. Time profiles of stearic acid hydrogenation using $\mathrm{Pd}-\mathrm{Sn}(1.5) / \mathrm{C}$ catalyst. Reaction conditions: catalyst $(0.05 \mathrm{~g})$; stearic acid $(0.2844 \mathrm{~g} ; \quad 1.0 \mathrm{mmol})$; solvent (2propanol $/ \mathrm{H}_{2} \mathrm{O}(5.0 \mathrm{~mL} ; 4.0: 1.0 \mathrm{v} / \mathrm{v})$; reaction temperature $\left(240{ }^{\circ} \mathrm{C}\right)$; initial $\mathrm{H}_{2}$ pressure (3.0 MPa).

\subsubsection{Catalytic reaction of various fatty acids}

To gain the catalyst effectivity on the hydrogenation of carboxylic acids, the catalytic reactions of various fatty acids, esters and typical dicarboxylic acid (e.g., levulinic acid) were carried and the results are summarized in Table 4.

Oleic acid was converted to oleyl alcohol (48.2\%), ester (14.5\%) and others (20.3\%) in the presence of $\mathrm{Pd}-\mathrm{Sn}(1.5) / \mathrm{C}$ catalyst (entry 1). The hydrogenation of methyla stearate yielded $63.2 \%$ stearyl alcohol (1-octadecanol) at 97\% conversion of methyl stearate (entry 2). The conversion of methyl stearate is much higher than that of stearic acid under the same reaction conditions as mentioned above (Table 3 , entry 3), suggesting the synthesis of fatty alcohols is more preferable from ester than that of its fatty acids [38]. Hydrogenation of palmitic acid gave $79.2 \%$ yield of 1 hexadecanol at $98.7 \%$ conversion (entry 3). When lauric acid and methyl laurate were used as substrate, the conversion were $100 \%$ and the high lauryl alcohol yields of 96-98\% were obtained (entries 4-5), which are in good agreement with the previous results using $\mathrm{Ni}-\mathrm{Sn}(1.5)$ alloy catalyst [40]. The hydrogenation of typical cellulosic biomassderived levulinic acid yielded 99\% of $\gamma$-valerolactone(GVL) without the formation of the side products (entry 6). This result indicates that the catalytic performances of bimetallic $\mathrm{Pd}-\mathrm{Sn}$ alloy better than bimetallic $\mathrm{Pd}-\mathrm{Fe}$ catalysts toward hydrogenation LA to GVL as reported by Damayanti et al. [39]. Moreover, the catalytic reaction of 1octadecanol gave $24.7 \%$ yield of hydrocarbon (C18) and small amount of unidentified product under the same reaction conditions (entry 7). This result suggests that the further reaction of the formed alcohol to another side product was occurred during the hydrogenation

Table 4. Results of the hydrogenation of various fatty acid using $\mathrm{Pd}-\mathrm{Sn}(1.5) / \mathrm{C}$ catalyst.

\begin{tabular}{|c|c|c|c|c|c|}
\hline \multirow{2}{*}{ Entry } & \multirow{2}{*}{ Substrate } & \multirow{2}{*}{ Conversion $^{a}(\%)$} & \multicolumn{3}{|c|}{ Yield $^{b}(\%)$} \\
\hline & & & Alcohol & Ester & Others $^{c}$ \\
\hline 1 & Oleic acid & 83 & 48.2 & 14.5 & 20.3 \\
\hline 2 & Methyl stearate & 97 & 69.2 & 0 & 27.8 \\
\hline 3 & Palmitic acid & 98.7 & 79.2 & 9.5 & 10 \\
\hline 4 & Lauric accid & 100 & 96 & 0 & 4 \\
\hline 5 & Methyl laurate & 100 & 98.2 & 0 & 1.8 \\
\hline 6 & Levulinic acid & 100 & 99 & $<0.1$ & $<0.1$ \\
\hline 7 & 1-octadecanol & 24.7 & - & - & 24.7 \\
\hline
\end{tabular}

Reaction conditions: catalyst $(0.05 \mathrm{~g})$; substrate $(0.2844 \mathrm{~g} ; 1.0 \mathrm{mmol})$; solvent (2-propanol/ $\left.\mathrm{H}_{2} \mathrm{O} ; 5.0 \mathrm{~mL} ; 4.0: 1.0 \mathrm{v} / \mathrm{v}\right)$; temperature $240{ }^{\circ} \mathrm{C}$; initial $\mathrm{H}_{2}$ pressure $(3.0 \mathrm{MPa})$; reaction time $(7 \mathrm{~h}) .{ }^{a}$ Conversion was determined by $\mathrm{GC}$ using an internal standard

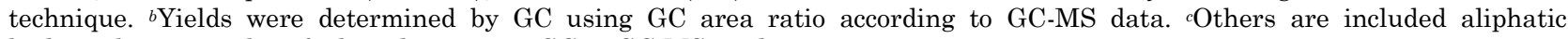
hydrocarbon or unidentified products using GC or GC-MS analyses. 
of stearic acid as indicated by the amount of others. To confirm this suggestion, ATR-IR analysis of the recovered catalyst was carried out and the results are shown in Figure 9. Two absorption peaks at wavenumber (v) $1067 \mathrm{~cm}^{-1}$

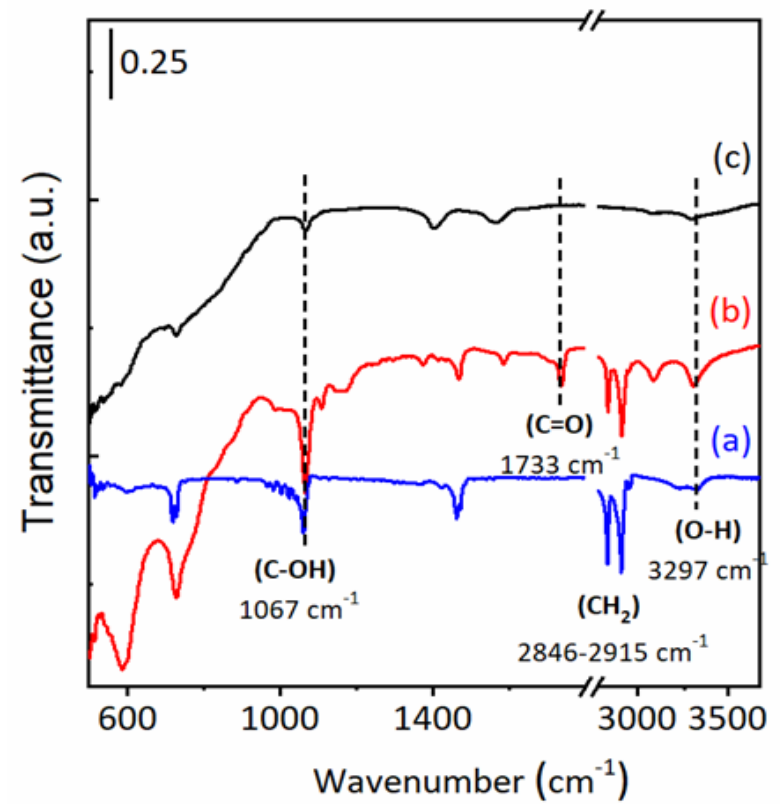

Figure 9. ATR-IR spectra of fresh and recovered catalysts and its possible interaction between Pd-Sn(1.5)/C catalyst and molecular reactant of stearic acid. (a) 1-octadecanol; (b) wetted recovered catalyst; (c) dried recovered catalyst. and $3297 \mathrm{~cm}^{-1}$ that can be assigned as $\mathrm{C}-\mathrm{O}$ and $\mathrm{O}-\mathrm{H}$ strechings, respectively. The presence of sharp peak at 2846-2915 $\mathrm{cm}^{-1}$ which can be assigned as $-\mathrm{CH}_{2}$ was also clearly observed. A small peak at $1733 \mathrm{~cm}^{-1}$ was observed at Figure $9 \mathrm{~b}$, which can be attributed as the $\mathrm{C}=\mathrm{O}$ functional group of remained stearic acid reactant. Additionally, the absorption peaks at around $1480 \mathrm{~cm}^{-1}$ and $720 \mathrm{~cm}^{-1}$ can be attributed as the $\mathrm{sp}^{3} \mathrm{C}-\mathrm{H}$ and $\mathrm{sp}^{2} \mathrm{C}-\mathrm{H}$ bends, respectively.

The profiles of reaction products obtained over $\mathrm{Pd} / \mathrm{C}$ catalyst significantly shifted toward 1-octadecanol (stearyl alcohol) after the introduction of $\mathrm{Sn}$ to form bimetallic $\mathrm{Pd}-\mathrm{Sn}(x) / \mathrm{C}$ catalysts as already described above. The results of substrate scope, evaluation of reaction parameters, and ATR-IR analysis are obviously good agreement with the reaction products. Therefore, the possible reaction mechanism of stearic acid hydrogenation is proposed as shown in Scheme 2. It has been reported that the decarboxylation reaction of stearic acid was favorable occurred than that of hydrogenation in the presence of $\mathrm{Pd} / \mathrm{C}$ catalyst and produced hydrocarbon (Scheme 2(a). Our results are in good agreement with the previous reports $[13,34]$. On the other hand, the high selectivity of alcohol over $\mathrm{Pd}-\mathrm{Sn}(x) / \mathrm{C}$ catalysts may be due to the increased oxyphilicity of the surface associated with the Sn cations which interact with the lone electron pair of carbonyl group

a)

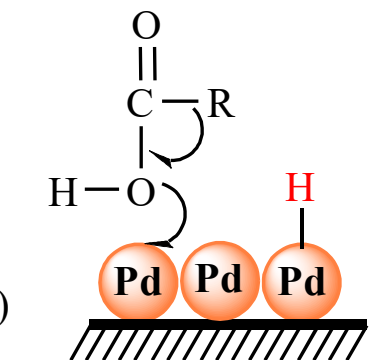

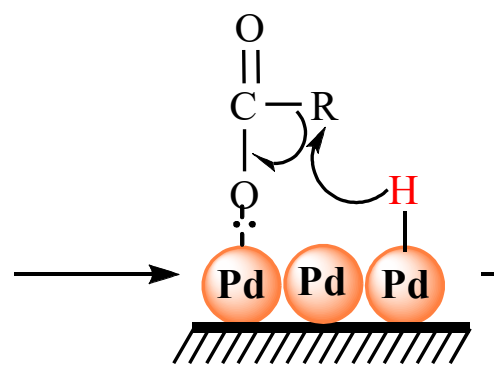<smiles>CCC[Fe]=O</smiles><smiles>[R]</smiles>
$+$ $\mathrm{CO}_{2}$ Hydrocarbon

b)

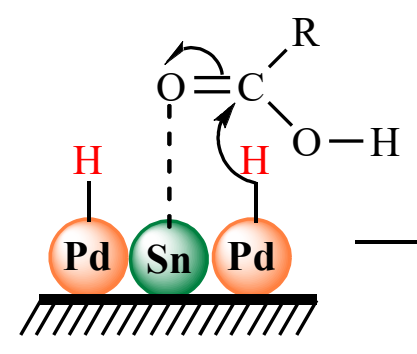<smiles></smiles><smiles>[R]C(O)[18OH]</smiles>

Alcohol

Scheme 2. Possible reaction mechanism for the hydrogenation of stearic acid using a) supported monometallic $\mathrm{Pd} / \mathrm{C}$ and b) supported bimetallic supported $\mathrm{Pd}-\mathrm{Sn}$ catalysts. 
oxygen, as depicted in Scheme 2(b). Takeda et al. suggested that Pd plays in a promoting the reduction and dispersion of $\mathrm{Re}$ species, and strengthening the interaction of stearic acid with the catalyst surface, while the presence of partially reduced Re promoted the heterolytic dissociation of $\mathrm{H}_{2}$ then finally enhanced the hydrogenation of stearic acid to stearyl alcohol [29]. Desphande also suggested that the interaction of the substrate with tin on the catalyst surface favours the formation of carbanion and aldehyde as the intermediate then rapidly hydrogenate to alcohol [25]. Similarly, Pallassana et al. [53] and Olcay et al. [54] have reported that carboxylic acid was adsorbed on the surface of $\operatorname{Pd}^{0}$ and $\operatorname{Re}^{0}$, and the activated heterolytically hydrogen as hydride species will attacks the adsorbed carboxylic acids and the hydrogenolysis of $\mathrm{C}-\mathrm{OH}$ proceeds to give the adsorbed aldehyde which easily hydrogenate to alcohol.

\section{Conclusions}

We described the selective hydrogenation of stearic acid to corresponding alcohol using Pdbased catalysts under mild reaction conditions. Bimetallic palladium-tin catalysts supported on microporous carbon (denoted as $\mathrm{Pd}-\mathrm{Sn}(x) / \mathrm{C}$, loading amount of $\mathrm{Pd}=5 \mathrm{wt} \%$ and $x=\mathrm{Pd} / \mathrm{Sn}$ molar ratio; c.a., 3.0; 1.5; and 1.0) showed high selectivity in the hydrogenation of stearic acid towards 1-octadecanol (stearyl alcohol). $\mathrm{Pd}-\mathrm{Sn}(1.5) / \mathrm{C}$ catalyst exhibited the highest yield of stearyl alcohol (1-octadecanol) (up to $73.2 \%$ ) at $100 \%$ conversion of stearic acid at temperature $240{ }^{\circ} \mathrm{C}$, initial $\mathrm{H}_{2}$ pressure of 3.0 $\mathrm{MPa}$, a reaction time of $13 \mathrm{~h}$, and in 2-propanol/water solvent. The high selectivity of alcohols over $\mathrm{Pd}-\mathrm{Sn}(1.5) / \mathrm{C}$ catalyst can be attributed to the formation of bimetallic $\mathrm{Pd}-\mathrm{Sn}$ alloy phases (e.g., $\mathrm{Pd}_{3} \mathrm{Sn}$ and $\mathrm{Pd}_{3} \mathrm{Sn}_{2}$ ) as obviously depicted by XRD analysis. The presence of co-promotor Sn and the formation of bimetallic may play a pivotal role in the high selectivity of 1-octadecanol.

\section{Acknowledgments}

The authors acknowledge the BPDP Kelapa Sawit, Ministry of Finance, the RISET DASAR \& Hibah Berbasis Kompetensi (HIKOM) FY 2018-2020, and the RISET DASAR FY 20192021 (contract number DIPA-042.061.401516/2020) from the Ministry of Research, Technology, and Higher Education, which all financially supported this work.

\section{References}

[1] Noweck, K., Grafahrend, W. (2012). Fatty alcohols. in: Ullmann's Encyclopedia of Industrial Chemistry, pp. 117-139. DOI: 10.1002/14356007.a10_277.pub2.

[2] Lestari, S., Mäki-Arvela, P., Beltramini, J., Lu, G.Q.M., Murzin, D.Y. (2009). Transforming triglycerides and fatty acids into biofuels, ChemSusChem, 2, 1109-1119. DOI: 10.1002/cssc.200900107.

[3] Pritchard, J., Filonenko, G.A., Van Putten, R., Hensen, E.J.M., Pidko, E.A. (2015). Heterogeneous and homogeneous catalysis for the hydrogenation of carboxylic acid derivatives: History, advances and future directions. Chemical Society Reviews, 44, 3808-3833. DOI: $10.1039 / \mathrm{c} 5 \mathrm{cs} 00038 \mathrm{f}$.

[4] Tamura, M., Nakagawa, Y., Tomishige, K. (2020). Recent Developments of Heterogeneous Catalysts for Hydrogenation of Carboxylic Acids to their Corresponding Alcohols. Asian Journal of Organic Chemistry, 9, 126143. DOI: 10.1002/ajoc.201900667.

[5] Sánchez, M.A., Torres, G.C., Mazzieri, V.A., Pieck, C.L. (2017). Selective hydrogenation of fatty acids and methyl esters of fatty acids to obtain fatty alcohols-a review. Journal of Chemical Technology and Biotechnology, 92, 27-42. DOI: 10.1002/jctb.5039.

[6] Turek, T., Trimm, D.L., Cant, N.W. (2007). The Catalytic Hydrogenolysis of Esters to Alcohols. Catalysis Reviews, 36, 645-683. DOI: 10.1080/01614949408013931.

[7] Lee, A.F., Bennett, J.A., Manayil, J.C., Wilson, K. (2014). Heterogeneous catalysis for sustainable biodiesel production via esterification and transesterification. Chemical Society Reviews, 43, 7887-7916. DOI: 10.1039/c4cs00189c.

[8] Folkers, K., Adkins, H. (1932). The catalytic hydrogenation of esters to alcohols. II. Journal of the American Chemical Society, 54, 1145-1154. DOI: 10.1021/ja01342a043.

[9] Rieke, R.D., Thakur, D.S., Roberts, B.D., White, G.T. (1997). Fatty methyl ester hydrogenation to fatty alcohol part I: Correlation between catalyst properties and activity/selectivity. Journal of the American Oil Chemists' Society. 74, 333-339. DOI: 10.1007/s11746-997-0088-y.

[10] Rieke, R.D., Thakur, D.S., Roberts, B.D., White, G.T. (1997). Fatty methyl ester hydrogenation to fatty alcohol part II: Process issues. Journal of the American Oil Chemists' Society, 74, 341-345. DOI: 10.1007/s11746997-0089-x. 
[11] Kon, K., Tayao, T., Onodera, W., Siddiki, S.M.A.H., Shimizu, K. (2017). Hydrodeoxygenation of Fatty Acids, Triglycerides, and Ketones to Liquid Alkanes by a Pt$\mathrm{MoOx} / \mathrm{TiO}_{2}$ Catalyst. Chem CatChem, 9, 28222827. DOI: $10.1002 /$ cctc.201700219.

[12] Schreiber, M.W., Rodriguez-Niño, D., Gutiérrez, O.Y., Lercher, J.A. (2016). Hydrodeoxygenation of fatty acid esters catalyzed by $\mathrm{Ni}$ on nano-sized MFI type zeolites. Catalysis Science \& Technology, 6, 7976-7984. DOI: 10.1039/c6cy01598k.

[13] Dawes, G.J.S., Scott, E.L., Le Nôtre, J., Sanders, J.P.M., Bitter, J.H. (2015). Deoxygenation of biobased molecules by decarboxylation and decarbonylation - A review on the role of heterogeneous, homogeneous and bio-catalysis. Green Chemistry, 17, 3231-3250. DOI: 10.1039/c5gc00023h.

[14] Veldsink, J.W., Bouma, M.J., Schöön, N.H., Beenackers, A.A.C.M. (1997). Heterogeneous Hydrogenation of Vegetable Oils: A Literature Review. Catalysis Reviews, 39, 253-318. DOI: 10.1080/01614949709353778.

[15] Sachtler, W.M.H., van Santen, R.A. (1977). Surface Composition and Selectivity of Alloy Catalysts. Advances in Catalysis, 26, 69-119. DOI: 10.1016/S0360-0564(08)60070-X.

[16] Ferrando, R., Jellinek, J., Johnston, R.L. (2008). ChemInform Abstract: Nanoalloys: From Theory to Applications of Alloy Clusters and Nanoparticles. ChemInform, 39. DOI: 10.1002/chin.200824213.

[17] Tomishige, K., Nakagawa, Y., Tamura, M. (2017). Selective hydrogenolysis and hydrogenation using metal catalysts directly modified with metal oxide species. Green Chemistry, 19, 2876-2924. DOI: 10.1039/c7gc00620a.

[18] Dandekar, A., Vannice, M.A. (1999). Crotonaldehyde hydrogenation on $\mathrm{Pt} / \mathrm{TiO}_{2}$ and $\mathrm{Ni} / \mathrm{TiO}_{2}$ SMSI catalysts. Journal of Catalysis, 183, 344-354. DOI: 10.1006/jcat.1999.2419.

[19] Corma, A., Serna, P., Concepción, P., Calvino, J.J. (2008). Transforming nonselective into chemoselective metal catalysts for the hydrogenation of substituted nitroaromatics. Journal of the American Chemical Society, 130, 8748-8753. DOI: 10.1021/ja800959g.

[20] Carnahan, J.E., Ford, T.A., Gresham, W.F., Grigsby, W.E., Hager, G.F. (1955). Ruthenium-catalyzed Hydrogenation of Acids to Alcohols. Journal of the American Chemical Society, 77, 3766-3768. DOI: 10.1021/ja01619a025.
[21] Vorotnikov, V., Eaton, T.R., Settle, A.E., Orton, K., Wegener, E.C., Yang, C., Miller, J.T., Beckham, G.T., Vardon, D.R. (2019). Inverse Bimetallic RuSn Catalyst for Selective Carboxylic Acid Reduction. ACS Catalysis, 9, 11350-11359. DOI: 10.1021/acscatal.9b02726.

[22] Wang, L., Weng, Y., Duan, P., Liu, X., Wang, X., Zhang, Y., Wang, C., Liu, Q., Ma, L. (2019). Influence of acid pretreatment on the hydrodeoxygenation performance of carbon supported RuMo bimetallic catalysts on sorbitol conversion. SN Applied Sciences, 1, 44. DOI: $10.1007 / \mathrm{s} 42452-019-0434-3$.

[23] Miyake, T., Makino, T., Taniguchi, S., Watanuki, H., Niki, T., Shimizu, S., Kojima, Y., Sano, M. (2009). Alcohol synthesis by hydrogenation of fatty acid methyl esters on supported Ru-Sn and Rh-Sn catalysts. Applied Catalysis A: General, 364, 108-112. DOI: 10.1016/j.apcata.2009.05.036.

[24] Luo, Z., Bing, Q., Kong, J., Liu, J.Y., Zhao, C. (2018). Mechanism of supported Ru3Sn7 nanocluster-catalyzed selective hydrogenation of coconut oil to fatty alcohols. Catalysis Science \& Technology, 8, 1322-1332. DOI: 10.1039/c8cy00037a.

[25] Deshpande, V.M., Ramnarayan, K., Narasimhan, C.S. (1990). Studies on Ruthenium-Tin Boride Catalysts II. Hydrogenation of Fatty Acid Esters to Fatty Alcohols Analysis of Products. Journal of Catalysis, 182, 174-182. DOI: 10.1016/0021-9517(90)90227-B.

[26] Deshpande, V.M., Patterson, W.R., Narasimhan, C.S. (1990). Studies on ruthenium-tin boride catalysts I. Characterization. Journal of Catalysis, 121, 165-173. DOI: 10.1016/0021-9517(90)90226-A.

[27] Manyar, H.G., Paun, C., Pilus, R., Rooney, D.W., Thompson, J.M., Hardacre, C. (2010). Highly selective and efficient hydrogenation of carboxylic acids to alcohols using titania supported Pt catalysts. Chemical Communications, 46, 6279-6281. DOI: 10.1039/c0cc01365j.

[28] Takeda, Y., Nakagawa, Y., Tomishige, K. (2012). Selective hydrogenation of higher saturated carboxylic acids to alcohols using a Re$\mathrm{Ox}-\mathrm{Pd} / \mathrm{SiO} 2$ catalyst. Catalysis Science \& Technology, 2, 2221-2223. DOI: 10.1039/c2cy20302b.

[29] Takeda, Y., Tamura, M., Nakagawa, Y., Okumura, K., Tomishige, K. (2015). Characterization of $\mathrm{Re}-\mathrm{Pd} / \mathrm{SiO}_{2}$ Catalysts for Hydrogenation of Stearic Acid. ACS Catalysis, 5, 70347047. DOI: 10.1021/acscatal.5b01054. 
[30] Rozmysłowicz, B., Kirilin, A., Aho, A., Manyar, H., Hardacre, C., Wärnå, J., Salmi, T., Murzin, D.Y. (2015). Selective hydrogenation of fatty acids to alcohols over highly dispersed $\mathrm{ReO} / \mathrm{TiO} 2$ catalyst. Journal of Catalysis, 328, 197-207. DOI: 10.1016/j.jcat.2015.01.003.

[31] Lu, J., Fu, B., Kung, M.C., Xiao, G., Elam, J.W., Kung, H.H., Stair, P.C. (2012). Cokingand sintering-resistant palladium catalysts achieved through atomic layer deposition. Science, $\quad 335, \quad 1205-1208$. DO : $10.1126 /$ science. 1212906 .

[32] Liao, F., Lo, T.W.B., Tsang, S.C.E. (2015). Recent Developments in Palladium-Based Bimetallic Catalysts. ChemCatChem, 7, 19982014. DOI: $10.1002 /$ cctc. 201500245 .

[33] Simakova, I., Simakova, O., Mäki-Arvela, P., Simakov, A., Estrada, M., Murzin, D.Y. (2009). Deoxygenation of palmitic and stearic acid over supported Pd catalysts: Effect of metal dispersion. Applied Catalysis A: General, $355, \quad 100-108$. D O I : 10.1016/j.apcata.2008.12.001.

[34] Mäki-Arvela, P., Snåre, M., Eränen, K., Myllyoja, J., Murzin, D.Y. (2008). Continuous decarboxylation of lauric acid over $\mathrm{Pd} / \mathrm{C}$ catalyst. Fuel, 87, 3543-3549. DOI: 10.1016/j.fuel.2008.07.004.

[35] Zhang, Z., Okejiri, F., Li, Y., Li, J., Fu, J. (2020). Hydrodecarboxylation of fatty acids into liquid hydrocarbons over a commercial $\mathrm{Ru} / \mathrm{C}$ catalyst under mild conditions. New Journal of Chemistry, 44, 7642-7646. DOI: 10.1039/d0nj00730g.

[36] Popov, S., Kumar, S. (2015). Rapid hydrothermal deoxygenation of oleic acid over activated carbon in a continuous flow process. Energy \& Fuels, 29, $3377-3384$. DOI: 10.1021/acs.energyfuels.5b00308.

[37] Immer, J.G., Kelly, M.J., Lamb, H.H. (2010). Catalytic reaction pathways in liquid-phase deoxygenation of C18 free fatty acids. Applied Catalysis A: General, 375, 134-139. DOI: 10.1016/j.apcata.2009.12.028.

[38] Ullrich, J., Breit, B. (2018). Selective Hydrogenation of Carboxylic Acids to Alcohols or Alkanes Employing a Heterogeneous Catalyst. ACS Catalysis, 8, 785-789. DOI: 10.1021/acscatal.7b03484.

[39] Damayanti, A.P., Dewi, H.P., Ibrahim, I., Rodiansono, R. (2020). Selective hydrogenation of levulinic acid to $\mathrm{Y}$-valerolactone using bimetallic Pd-Fe catalyst supported on titanium oxide. IOP Conference Series: Materials Science and Engineering, 980, 012013. DOI: 10.1088/1757-899X/980/1/012013.
[40] Rodiansono, R., Pratama, M.I., Astuti, M.D., Abdullah, A., Nugroho, A., Susi, S. (2018). Selective Hydrogenation of Dodecanoic Acid to Dodecane-1-ol Catalyzed by Supported Bimetallic Ni-Sn Alloy. Bulletin of Chemical Reaction Engineering \& Catalysis, 13(2), 311-319. https://doi.org/10.9767/bcrec.13.2.1790.311319.

[41] Mustikasari, K., Rodiansono, R., Astuti, M.D., Husain, S., Sutomo, S. (2021). The promotion effect of $\mathrm{Cu}$ on the $\mathrm{Pd} / \mathrm{C}$ catalyst in the chemoselective hydrogenation of unsaturated carbonyl compounds. Bulletin of Chemical Reaction Engineering \& Catalysis, 16(2), 267-279. DOI: 10.9767/bcrec.16.2.10398.267279.

[42] Rodiansono, R., Astuti, M.D., Hara, T., Ichikuni, N., Shimazu, S. (2019). One-pot selective conversion of $\mathrm{C} 5$-furan into 1,4pentanediol over bulk Ni-Sn alloy catalysts in an ethanol/H2O solvent mixture. Green Chemistry, 21, 2307-2315. DOI: 10.1039/c8gc03938k.

[43] Rodiansono, R., Khairi, S., Hara, T., Ichikuni, N., Shimazu, S. (2012). Highly efficient and selective hydrogenation of unsaturated carbonyl compounds using Ni-Sn alloy catalysts. Catalysis Science \& Technology, 2, 21392145. DOI: 10.1039/c2cy20216f.

[44] Lowell, S., Shields, J.E., Thomas, M.A., Thommes, M. (2004). Characterization of Porous Solids and Powders: Surface Area, Pore Size and Density. Springer Netherlands, Dordrecht. DOI: 10.1007/978-1-4020-2303-3.

[45] Aben, P.C. (1968). Palladium areas in supported catalysts. Determination of palladium surface areas in supported catalysts by means of hydrogen chemisorption. Journal of Catalysis, 10, 224-229. DOI: 10.1016/S00219517(68)80002-8.

[46] Xu, Q., Kharas, K.C., Croley, B.J., Datye, A.K. (2011). The Sintering of Supported Pd Automotive Catalysts. ChemCatChem, 3, 1004-1014. DOI: 10.1002/cctc.201000392.

[47] Liakakou, E.T., Heracleous, E., Triantafyllidis, K.S., Lemonidou, A.A. (2015). Kpromoted NiMo catalysts supported on activated carbon for the hydrogenation reaction of $\mathrm{CO}$ to higher alcohols: Effect of support and active metal. Applied Catalysis B: Environmental, 165, 296-305. DOI: 10.1016/j.apcatb.2014.10.027.

[48] JCPDS-ICDD. (1991). Powder diffraction files, JCPDS-International center for diffraction data (JCPDS-ICDD). 
[49] Doronkin, D.E., Wang, S., Sharapa, D.I., Deschner, B.J., Sheppard, T.L., Zimina, A., Studt, F., Dittmeyer, R., Behrens, S., Grunwaldt, J.D. (2020). Dynamic structural changes of supported Pd, PdSn, and PdIn nanoparticles during continuous flow high pressure direct H2O2 synthesis. Catalysis Science \& Technology, 10, 4726-4742. DOI: 10.1039/d0cy00553c.

[50] Li, R., Zhao, J., Han, D., Li, X. (2017). Pd/C modified with Sn catalyst for liquid-phase selective hydrogenation of maleic anhydride to gamma-butyrolactone. Chinese Chemical Letters, 28, 1330-1335. D O I : 10.1016/j.cclet.2017.04.028.

[51] Kandel, K., Chaudhary, U., Nelson, N.C., Slowing, I.I. (2015). Synergistic Interaction between Oxides of Copper and Iron for Production of Fatty Alcohols from Fatty Acids. ACS Catalysis, 5, 6719-6723. DOI: 10.1021/acscatal.5b01664.
[52] Kong, X., Fang, Z., Bao, X., Wang, Z., Mao, S., Wang, Y. (2018). Efficient hydrogenation of stearic acid over carbon coated $\mathrm{Ni}-\mathrm{Fe}$ catalyst. Journal of Catalysis, 367, 139-149. DOI: 10.1016/j.jcat.2018.08.022.

[53] Pallassana, V., Neurock, M. (2002). Reaction paths in the hydrogenolysis of acetic acid to ethanol over Pd(111), Re(0001), and PdRe alloys. Journal of Catalysis, 209, 289-305. DOI: 10.1006/jcat.2002.3585.

[54] Olcay, H., Xu, L., Xu, Y., Huber, G.W. (2010). Aqueous-phase hydrogenation of acetic acid over transition metal catalysts. ChemCatChem, 2, 1420-1424. DOI: 10.1002/cctc.201000134. 